DOI: $10.5800 / G T-2021-12-3-0542$

\title{
LITHOLOGICAL AND FACIAL FEATURES, COMPOSITION, AND SEDIMENTATION CONDITIONS OF TERRIGENOUS-CARBONATE ROCKS OF THE MOTY GROUP (SHAMAN CLIFF, IRKUTSK REGION)
}

\author{
Z.L. Motova $\oplus^{1 凶}$, A.V. Plyusnin $\oplus^{2}$, E.V. Nikulin ${ }^{2}$ \\ ${ }^{1}$ Institute of the Earth's Crust, Siberian Branch of the Russian Academy of Sciences, 128 Lermontov St, Irkutsk 664033, \\ Russia \\ ${ }^{2}$ Irkutsk Oil Company LLC, 4 Bolshoy Liteiny Ave, Irkutsk 664007, Russia
}

ABSTRACT. We have studied terrigenous-carbonate rocks in the area near the Sayan mountains in the Irkutsk Region (Russia), specifically at the Shaman Cliff, being the stratotype area of rocks that belong to the Moty group. The cliff's lower part is composed of sandstones, which fragments gradually decrease in size upward the cross-section. The middle and upper parts are composed of sandy dolomites and dolomites, respectively. In terms of material characteristics, the terrigenous rocks correspond to arkoses. According to the genetic typification, the arkoses are composed of destructed primary igneous rocks. The terrigenous-carbonate rocks contain a carbonate component that gradually increases in the upper part of the cross-section. In the Shaman Cliff cross-section, we distinguish 32 lithological units and eight lithologicalgenetic types of deposits. Paleogeodynamic conditions are reconstructed for the formation of the sedimentation basin. Our study of the Shaman formation reveals specific features of the lithological facies, which suggest that these rocks accumulated in a coastal environment affected by tides. In the study area, clastic materials were mainly removed from an orogen that formed due to the Vendian accretion-collision events in the southern folded frame of the Siberian platform. Dolomites composing the upper part of the cliff are attributed to the Irkutsk formation of the Moty group. Their lithological features give evidence of shallow-marine conditions of their formation, without any supply of clastic material, which contributed to mass dispersal of the Cambrian biota described in [Marusin et al., 2021]. It is our first initiative to draw a boundary between the Shaman and Irkutsk formations of the Moty Group along the base of the carbonate eluvial breccia unit that marks the stratigraphic break. In the cross-section, this boundary represents the border between the Upper Vendian and Lower Cambrian.

Our conclusions are generally consistent with the ideas of most researchers about the Late Vendian evolution of the southern margin of the Siberian platform. The results of our study can be used in further investigation of this area and provide a basis for correlating the studied strata with the same-age reference cross-sections of other regions in Siberia.

KEYWORDS: Siberian platform; Irkutsk Region; area near the Sayan mountains; Shaman formation; Irkutsk formation; Vendian; Cambrian; terrigenous rocks; carbonate rocks; Shaman Cliff; lithochemistry; analysis of lithological facies; paleogeodynamics

FUNDING: The study was supported by the Russian Foundation for Basic Research (project 19-05-00266) and the Government of the Russian Federation (project 075-15-2019-1883). In part, this work involved the equipment of the Centre of Geodynamics and Geochronology (Institute of the Earth's Crust, Siberian Branch of the Russian Academy of Sciences).

\section{RESEARCH ARTICLE}

Received: June 2, 2021

Revised: July 6, 2021

Correspondence: Zinaida L. Motova, motova@crust.irk.ru Accepted: July 12, 2021

FOR CITATION: Motova Z.L., Plyusnin A.V., Nikulin E.V., 2021. Lithological and facial features, composition, and sedimentation conditions of terrigenous-carbonate rocks of the Moty group (Shaman Cliff, Irkutsk Region). Geodynamics \& Tectonophysics 12 (3), 628-644. doi:10.5800/GT-2021-12-3-0542 


\title{
ЛИТОЛОГО-ФАЦИАЛЬНЫЕ ОСОБЕННОСТИ, ВЕЩЕСТВЕННЫЙ СОСТАВ И УСЛОВИЯ СЕДИМЕНТАЦИИ ТЕРРИГЕННО-КАРБОНАТНЫХ ПОРОД МОТСКОЙ СЕРИИ («ШАМАНСКИЙ УТЕС», ИРКУТСКОЕ ПРИСАЯНЬЕ)
}

\author{
3.Л. Мотова ${ }^{1}$, А.В. Плюснин ${ }^{2}$, Е.В. Никулин ${ }^{2}$
}

${ }^{1}$ Институт земной коры СО РАН, 664033, Иркутск, ул. Лермонтова, 128, Россия

${ }^{2} 000$ «Иркутская нефтяная компания», 664007, Иркутск, Большой Литейный пр-т, 4, Россия

АНнотАЦИЯ. В работе представлены результаты изучения вещественных (литохимических) и фациальных характеристик терригенно-карбонатных пород мотской серии, изученных в их стратотипической местности (разрез «Шаманский утес»). Показано, что породы, слагающие нижнюю часть разреза «Шаманский утес», представлены песчаниками, размер обломков которых постепенно уменьшается вверх по разрезу. Средняя часть разреза сложена песчанистыми доломитами. Завершают разрез доломиты. По своим вещественным характеристикам терригенные породы соответствуют аркозам. Генетическая типизация, выполненная с применением петрохимических модулей, свидетельствует о том, что эти аркозы сложены продуктами разрушения первично-магматических пород. Выявлено постепенное увеличение карбонатной составляющей в вещественном составе терригенно-карбонатных пород верхних частей разреза. В разрезе «Шаманский утес» выделено 32 литологические пачки и восемь литолого-генетических типов отложений. Реконструированы палеогеодинамические условия формирования бассейна седиментации. Литолого-фациальные особенности пород шаманской свиты свидетельствуют о том, что они накапливались в условиях приливно-отливного побережья. Основной снос обломочного материала происходил с орогена, возникшего в результате вендских аккреционно-коллизионных событий, проявленных в южном складчатом обрамлении Сибирской платформы. Доломиты, слагающие верхние части изученного разреза, отнесены к иркутской свите мотской серии. Литолого-фациальные особенности этих доломитов свидетельствуют о мелководно-морских условиях их образования, без поступления обломочного материала, что способствовало массовому расселению кембрийской биоты, охарактеризованной в работе [Marusin et al., 2021]. Авторами впервые предложено провести границу между шаманской и иркутской свитами мотской серии по подошве реперной пачки, представленной карбонатной элювиальной брекчией, которая фиксирует стратиграфический перерыв, и определить ее как границу верхнего венда и нижнего кембрия в изученном разрезе.

В целом, сформулированные в настоящей работе выводы не противоречат представлениям большинства исследователей о поздневендской эволюции южной окраины Сибирской платформы и закладывают основу для дальнейших исследований в данном районе с последующей корреляцией изученных толщ с одновозрастными опорными разрезами других регионов Сибири.

КЛЮЧЕВЫЕ СЛОВА: Сибирская платформа; Иркутское Присаянье; шаманская свита; венд; иркутская свита; кембрий; терригенные породы; карбонатные породы; Шаманский утес; литохимия; литолого-фациальный анализ; палеогеодинамика

ФИНАНСИРОВАНИЕ: Исследования выполнены при поддержке РФФИ (проект № 19-05-00266) и Правительства Российской Федерации (проект № 075-15-2019-1883). В работе частично задействовалось оборудование ЦКП «Геодинамика и геохронология» Института земной коры СО РАН.

\section{1. ВВЕДЕНИЕ}

Мощные комплексы осадочных пород позднерифейско-вендского возраста широко распространены вдоль южной периферии Сибирской платформы и участвуют в строении Саяно-Байкало-Патомского пояса (СБПП), в пределах которого выделены саянский, байкальский и патомский сегменты [Savitsky et al., 1983]. В соответствии с Унифицированной стратиграфической схемой [Savitsky et al., 1983], осадочные комплексы СБПП подразделены на региональные стратиграфические горизонты (снизу вверх): пурпольский, медвежевский, баллаганахский, дальнетайгинский, жуинский и присаянский. Каждый из этих горизонтов отражает определенный этап в эволюции южной периферии Сибирской платформы: внутриконтинентальное растяжение, режим пассивной континентальной окраины
Палеоазиатского океана, формирование которой связано с распадом суперконтинента Родиния в позднем рифее, а также обстановку бассейна форланда [Gladkochub et al., 2019, и ссылки в данной работе]. Терригенно-карбонатные породы присаянского горизонта вверх по разрезу сменяются кембрийскими породами усольского горизонта. Ранее возраст присаянского регионального стратиграфического горизонта было принято считать поздневендским (юдомским) на основании межрегиональных стратиграфических исследований [Khomentovsky et al., 1972; Sovetov, 1977; Savitsky et al., 1983; Stanevich et al., 2006; Sovetov et al., 2007]. По мнению ряда исследователей, поздневендская (юдомская) седиментация на южной окраине Сибирской платформы происходила в два этапа. Раннеюдомское осадконакопление имело место на фоне орогенных событий, 
в результате которых у южной окраины платформы возникла система горных сооружений и впадин. Комплексы терригенных пород этого этапа характеризуются большими мощностями, полимиктовым составом и увеличением размерности обломочного материала вверх по разрезу. В позднеюдомский этап в мелководноморских условиях формировались карбонатно-терригенные отложения. Заполнение остаточных впадин этими отложениями привело к нивелированию рельефа и формированию относительно мелководного обширного моря, которое к началу кембрия распространилось по всей площади платформы [Salop, 1964; Khomentovsky et al., 1972; Sovetov, Blagovidov, 2004; Sklyarov, 2006; Stanevich et al., 2006, 2007; Sovetov, 2018; Gladkochub et al., 2019; и др.].

В Иркутском Присаянье (саянский сегмент СБПП) толща терригенно-карбонатных пород, относимая к присаянскому региональному стратиграфическому горизонту, выделена как мотская серия, разрез которой состоит из свит (снизу вверх): хужирской, шаманской

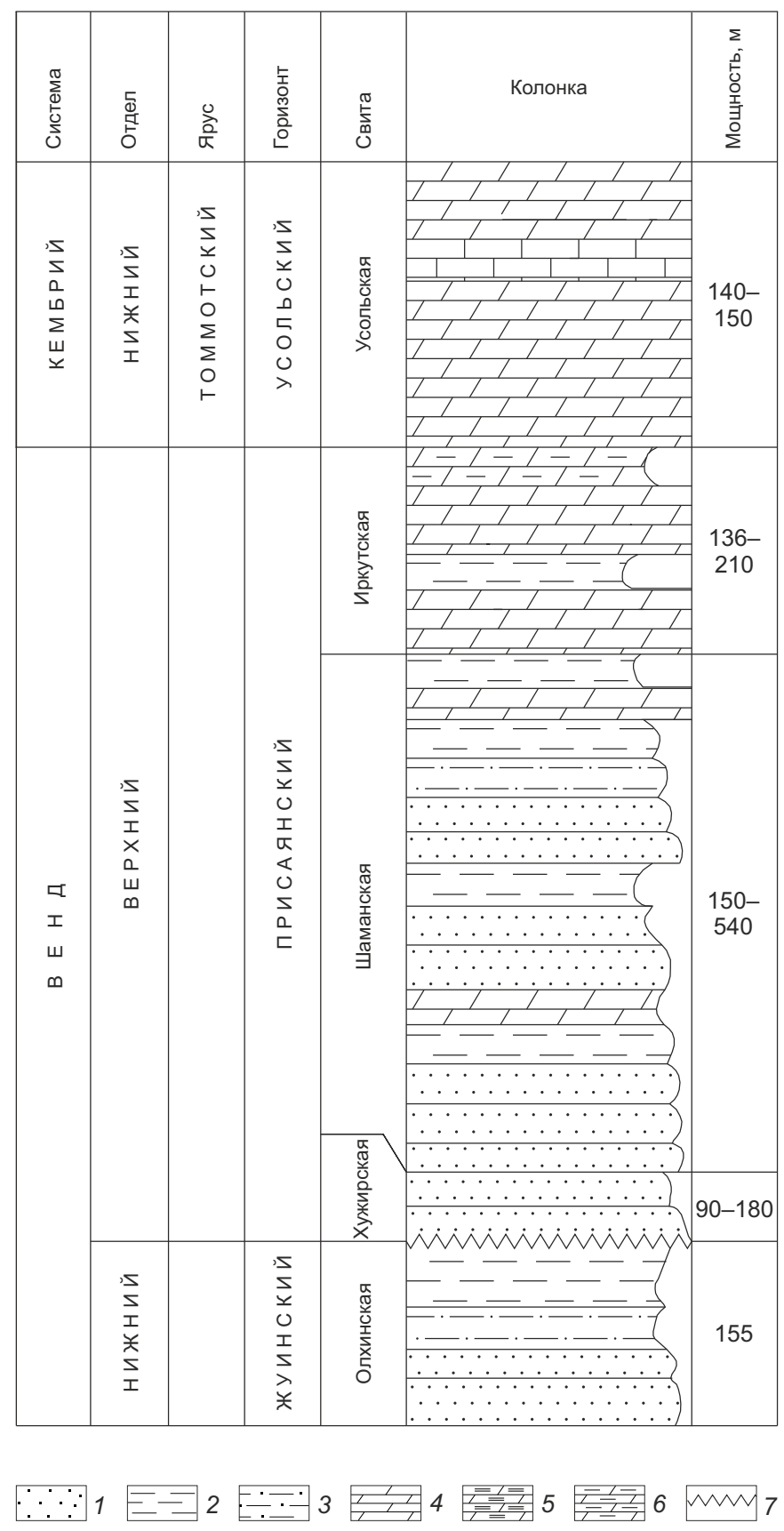

Рис. 1. Литологическая колонка осадочного чехла района исследования (модифицирована после [State Geological Map..., 2013]). 1 - песчаники; 2 - аргиллиты; 3 - алевролиты; 4 - доломиты; 5 - известняки; 6 - карбонатные брекчии; 7 - несогласное залегание.

Fig. 1. Lithological column of the sedimentary cover of the study area (modified after [State Geological Map..., 2013]). 1 - sandstone; 2 - mudstone; 3 - siltstone; 4 - dolomite; 5 - limestone; 6 - carbonate breccia; 7 - unconformity. 
и иркутской [Savitsky et al., 1983; Makhlaev, 2002]. Мотская серия с несогласием залегает на ранневендской олхинской свите [Shenfil, 1991; Sovetov, 2018] и перекрыта усольской свитой раннего кембрия, представленной соленосными карбонатными породами [Shabanov, 2016] (рис. 1). В последнее время в результате биостратиграфических, хемостратиграфических и U-Pb (LA-ICP-MS) геохронологических исследований зерен детритового циркона [Marusin et al., 2021] было показано, что иркутская свита мотской серии Иркутского Присаянья формировалась уже во втором веке кембрия (в соответствии с Международной хроностратиграфической шкалой (https://stratigraphy.org/chart)) или в томмотском ярусе кембрия (в соответствии с Общей стратиграфической шкалой России [Zhamoyda, 2019]), что поставило под сомнение сложившееся мнение о поздневендском возрасте всех пород, входящих в состав мотской серии. С целью выявления особенностей седиментационной структуры и литофациальной изменчивости а также последующей интерпретации палеогеодинамических условий авторами были проведены детальные литолого-фациальные и литохимические исследования терригенных пород мотской серии в стратотипической местности обнажение «Шаманский утес».

\section{2. МАТЕРИАЛЫ И МЕТОДЫ}

Основой для работы послужили результаты изучения геологического разреза «Шаманский утес», расположенного в уступе второй надпойменной террасы на левом берегу реки Иркут, в 500 м ниже по течению от деревни Шаманка, которая находится в 56 км от г. Иркутска (Шелеховский район Иркутской области). Размеры разреза: протяженность 500 м, высота около 122 м от уреза воды р. Иркут. На дневной поверхности этого разреза обнажены терригенные породы шаманской свиты (мощность около 100 м) и карбонатные иркутской свиты (около 22 м). С применением скалолазного оборудования произведено вертикальное описание по наиболее обнаженной части разреза с отбором 47 образцов (рис. 2).

Исследование образцов произведено в лаборатории 000 «Арктик-ГЕРС» (г. Тверь). Минералогический состав пород изучен методом рентгенофазового анализа (РСA) с использованием рентгено-дифрактометрического метода на приборе ДРОН-3М, регистрирующем дифракционную картину с помощью счетчика квантов. Результаты анализа поступали на ЭВМ; для обработки и интерпретации спектрограмм применялись специальные программные средства со встроенной библиотекой эталонных спектрограмм. Анализ петрогенных оксидов выполнен рентгенофлуоресцентным методом (РФлА) в лаборатории 000 «Арктик-ГЕРС» (г. Тверь) на рентгеновском спектрометре Axios mAX Advanced производства компании PANalytical (Нидерланды), по методикам, утвержденным Научным советом по аналитическим методам Всероссийского научно-исследовательского института минерального сырья. Выполнение анализа по данным методикам обеспечивает получение результатов 3-й категории точности количественного анализа по ОСТ РФ 41-08-205-04. (Пределы обнаружения - на уровне $0.0005-0.0010$ мас. \% (или 5-10 г/т) при воспроизводимости результатов не ниже 2 отн. \%.

При литологических исследованиях использованы общепринятые классификации по вещественному составу, структурно-генетическим признакам терригенных и карбонатных пород, изложенные в работах отечественных авторов [Vishnyakov, 1933; Kuznetsov, 2011; Maslov, 2005].
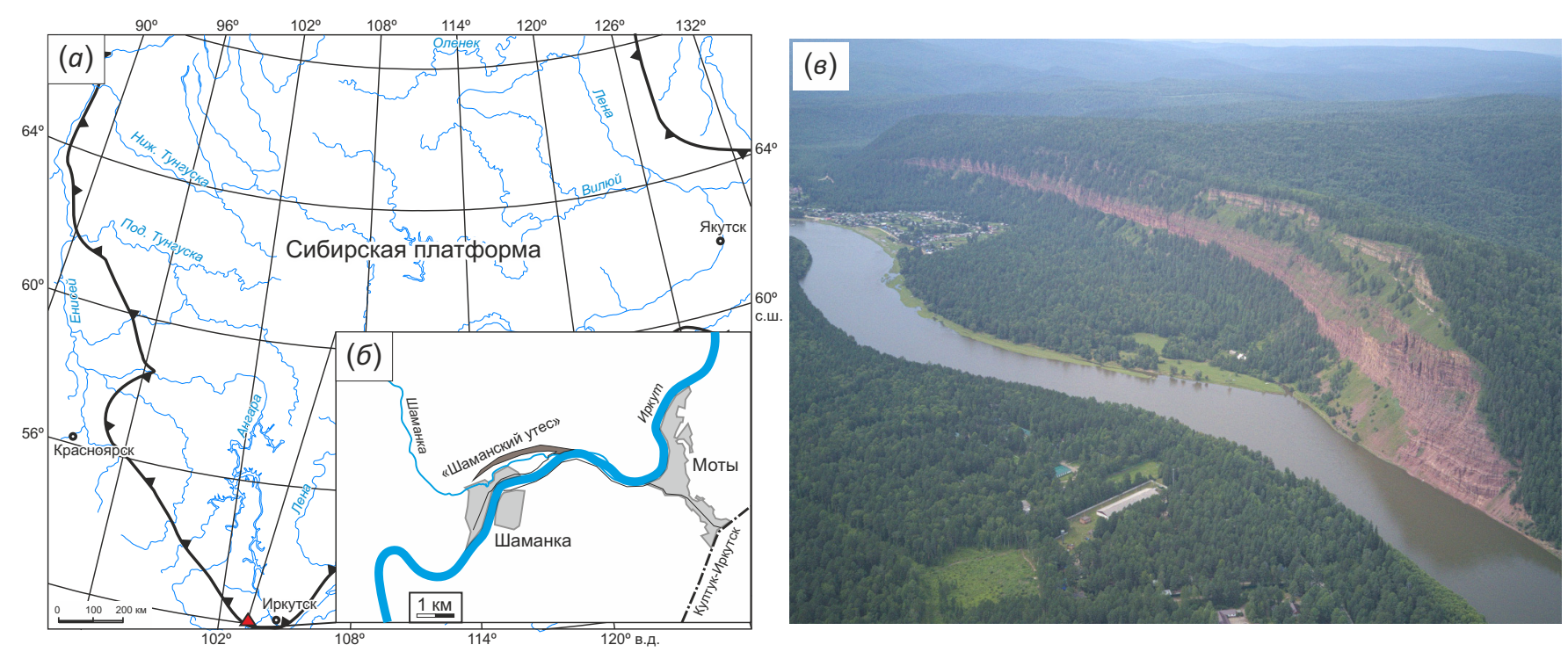

Граница Сибирской платфрормы

$\Delta$ Местоположение разреза

Рис. 2. Местоположение района исследования $(a$, б) и общий вид на разрез «Шаманский утес» $(8)$.

Fig. 2. Location of the study area $(a$, б). General view of the Shaman cliff cross-section $(b)$. 
Фациальные реконструкции выполнены на основе седиментационных моделей, разработанных известными специалистами в этой области [Reinek, Singkh, 1981; Selly, 1989].

Литохимическая классификация терригенно-карбонатных пород мотской серии проведена по методике Ф.Дж. Петтиджона [Pettijohn et al., 1976]. Для генетической типизации была использована система петрохимических модулей (по [Yudovich, Ketris, 2000]). Вещественный состав карбонатных пород определен с помощью расчета нормативного минерального состава с применением программы MINLITH [Rosen et al., 2000].

\section{3. КРАТКИЙ ГЕОЛОГИЧЕСКИЙ ОЧЕРК}

Терригенно-карбонатные породы мотской серии узкой непрерывной полосой прослежены вдоль предгорьев Восточного Саяна от р. Онот до верхнего течения p. Олха и полого погружаются в север-северо-восточном направлении под палеозойские образования чехла Сибирской платформы. В составе мотской серии, согласно Решениям межведомственного стратиграфического комитета CCCP [Savitsky et al., 1983] и утвержденной Легенде Ангаро-Енисейской серии листов ГК-1000/3 [Makhlaev, 2002], выделены (снизу вверх): хужирская, шаманская и иркутская свиты (см. рис. 1).

Хужирская свита со стратиграфическим несогласием залегает на подстилающих аргиллитах и алевролитах олхинской свиты раннего венда. В основании свиты отмечен горизонт разногалечных конгломератов. Низы разреза свиты сложены средне- и крупнозернистыми песчаниками, сменяющимися вверх по разрезу переслаиванием гравелитов, песчаников, алевролитов, аргиллитов. Завершает разрез толща красно-бурых разнозернистых песчаников с маломощными прослоями мелкогалечных конгломератов. Для терригенных пород хужирской свиты характерна сероцветность, полимиктовый состав, грубозернистость, плохая сортировка обломочного материала и наличие косой слоистости. Мощность свиты составляет от 90 до 180 м [Khomentovsky et al., 1972; State Geological Map..., 2009].

Шаманская свита согласно перекрывает хужирскую свиту. Низы разреза шаманской свиты представлены кварцевыми песчаниками - белыми, светло-зелеными, темно-серыми с маломощными прослоями мелкогалечных конгломератов, алевролитов и аргиллитов. Выше по разрезу наблюдается чередование вишневых кварцевых песчаников, пестроцветных алевролитов и тонких прослоев доломитов. Для пород свиты характерна тонкая ритмичность трансгрессивного типа с мощностью ритмов от долей метра до нескольких метров. Мощность свиты колеблется от 170 до 540 м [State Geological Map..., 2009].

Иркутская свита завершает разрез мотской серии и согласно, с постепенными переходами, перекрывает шаманскую свиту. В основании иркутской свиты залегают темно-серые, коричнево-красные доломиты и известняки с прослоями пестроцветных алевролитов, аргиллитов и песчаников. Завершается разрез свиты пестроцветными доломитами с редкими маломощными прослоями песчаников и алевролитов. Мощность иркутской свиты изменяется от 136 до 210 м [State Geological Map..., 2009]. Породы иркутской свиты согласно перекрываются ритмично чередующимися пластами каменной соли, ангидритов и доломитов усольской свиты 2-го яруса кембрия (в соответствии с Международной хроностратиграфической шкалой) [Shabanov, 2016].

\section{4. ЛИТОЛОГИЧЕСКАЯ ХАРАКТЕРИСТИКА РАЗРЕЗА}

Ниже приведено краткое описание выделенных пачек в разрезе (снизу вверх) (рис. 3).

1. Песчаники красновато-серые, крупнозернистые, слабоизвестковистые, с чередованием косой разнонаправленной и мульдообразной мелкой косой слойчатости ряби течений, с окатанными обломками метаморфических и магматических горных пород размером от 0.5 до 2.0 см, с угловато-окатанными интракластами алевролита размером от $0.3 \times 0.5$ до $2.0 \times 2.0$ см. Мощность пачки $3.5 \mathrm{M}$.

2. Песчаники красновато-серые, грубозернистые, слабоизвестковистые, с крупной косой разнонаправленной слоистостью, с окатанными обломками метаморфических и магматических горных пород размером от 0.8 до 2.5 см и редкими угловато-окатанными интракластами алевролита размером от $0.9 \times 1.5$ до 3.0×3.0 см. Контакт с нижележащим слоем четкий, эрозионный. Мощность пачки 3.0 м.

3. Песчаники красновато-серые, крупнозернистые, слабоизвестковистые, с чередованием косой разнонаправленной и волнистой прерывистой слоистости, с угловато-окатанными интракластами алевролита размером от $0.3 \times 0.5$ до $2.0 \times 2.0$ см, с редкими окатанными обломками метаморфических пород размером от 0.5 до 1.5 см. Контакт с нижележащим слоем четкий, переход постепенный. Мощность пачки 4.0 м.

4. Песчаники, идентичные описанным в слое 2. Контакт с нижележащим слоем четкий, эрозионный. Мощность пачки 3.75 м.

5. Переслаивание песчаников и алевролитов. Песчаники буровато-серые, мелкозернистые, известковые, с восходящей рябью течений. Алевролиты песчанистые, коричневато-серые, известковые, тонковолнисто-слоистые. Песчаники образуют ритмы мощностью от 0.5 до 1.0 м, алевролиты - мощностью от 0.2 до 0.4 м. Контакт с нижележащим слоем четкий, переход постепенный. Мощность пачки 4.0 м.

6. Песчаники красновато-серые, крупнозернистые, известковистые, с чередованием косой разнонаправленной и волнистой прерывистой слоистости, в верхней части слоя с текстурами гравитационного оползания, с угловато-окатанными интракластами алевролита размером от $0.4 \times 0.7$ см до $1.5 \times 2.0$ см и редкими окатанными обломками метаморфических пород размером от 0.5 до 1.0 см. Контакт с нижележащим слоем четкий, эрозионный. Мощность пачки 4.25 м. 


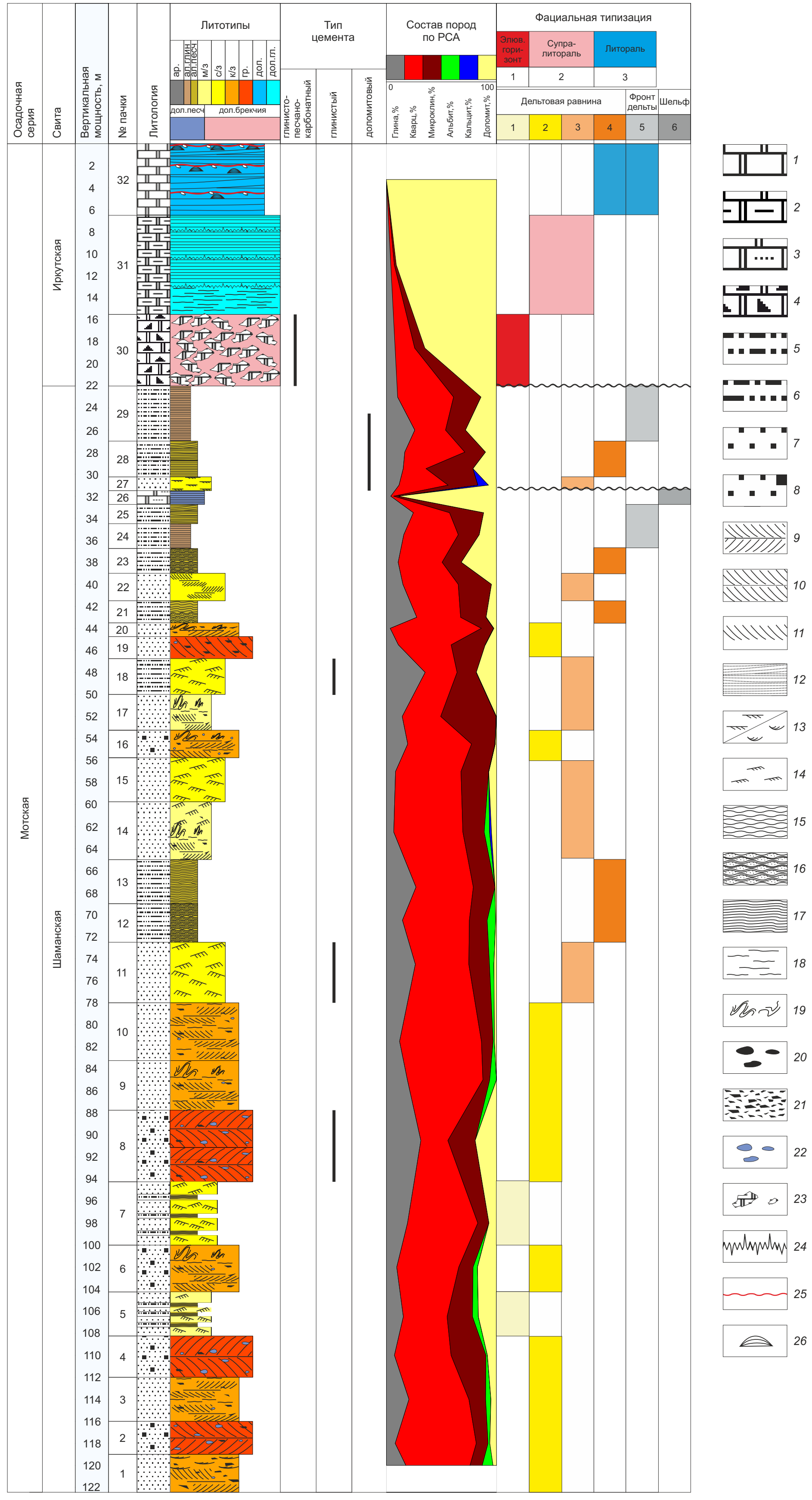

Рис. 3. Геологический разрез «Шаманский утес». Литотипы: ap. - аргиллит, ал. глин. - алевролит глинистый, ал. песч. - алевролит песчанистый, м/з - песчаник мелкозернистый, с/3 - песчаник среднезернистый, к/з - песчаник крупнозернистый, гр. - гравелит, дол. - доломит, дол. гл. - доломит глинистый, дол. песч. - доломит песчанистый, дол. брекчия - доломитовая брекчия. Фациальная зональность: дельтовая равнина: 1 - пески разлива, 2 - распределительные каналы (с влиянием приливно-отливных течений), 3 - приливноотливные каналы, 4 - межканальные участки, 5 продельта, 6 - шельф. Элювиальный горизонт (1), супралитораль (2), литораль (3).

Условные обозначения: Литология (1-8): 1 - доломиты, 2 - доломиты глинистые, 3 - доломиты песчанистые, 4 - доломиты брекчированные, 5 - алевролиты глинистые, 6 - алевролиты песчанистые, 7 - песчаники 8- гесчаники грубозернитье Текстурные особенности пород (9-19): 9 - косая разнонаправленная слоистость, 10 - таблитчатая крупная косая слоистость, 11 - косая слоистость, 12 субгоризонтальная слойчатость, 13 - мелкая косая слойчатость ряби течения (таблитчатая/мульдообразная), 14-- восходящая рябь течения, 15 -волнистость, 17 - тонкая пологоволнистая слоистость, 18 - волнистая прерывистая и нечеткая слоистость 19 - текстуры конседиментационных деформаций. Прочие обозначения (20-26): 20 - галька аргилмагматических и метаморфических пород, 23 - субаэральные брекчии, 24 - стилолиты, 25 - крупные эрозионные поверхности, 26 - строматолиты.

Fig. 3. Geological cross-section of the Shaman Cliff. Lithology: ap. - mudstone, ал. глин. - clayey siltstone, ал. песч. - sandy siltstone, м/з - fine-grained sandstone, $\mathrm{c} / 3$ - medium-grained sandstone, $\mathrm{K} / 3$ - coarsegrained sandstone, гр. - gravelite, дол. - dolomite, дол. гл - clayey dolomite дол песч - sandy dolomite, дол брекчия - dolomite breccia. Facies zoning of the delta plain: 1 - floodplain sands, 2 - distribution channels (influenced by tidal currents), 3 - tidal channels, 4 - interchannel areas, 5 - prodelta, 6 - shelf. Eluvial horizon (1), supralittoral (2), littoral (3).

Legend: Lithology (1-8): 1 - dolomite, 2 - clayey dodolomite 4 - brecciated dolomite, 5 clayey siltstone, 6 - sandy siltstone, 7 - sandstone, 8 coarse-grained sandstone. Texture features of rocks (9-19): 9 - oblique multidirectional bedding, 10 - tabular large oblique bedding 11 - oblique bedding 12 subhorizontal lamination, 13 - shallow oblique lamination of the ripples of the current (tabular / troughnation of the ripples of the current (tabular / trough-
shaped), 14 - ascending ripples of the current, 15- wavy bedding, 16 - lenticular-layered waviness, 17 - thin gently wavy bedding, 18 - wavy intermittent and indistinct bedding, 19 - textures of consedimentation deformations. Other signs (20-26): 20- mudstone pebble, 21 - siltstone intraclast, 22 - fragments of igneous and metamorphic rocks, 23 - subaerial breccia 24 - stylolite, 25 - large erosional surface, 26 - stromatolite. 
7. Переслаивание песчаников среднезернистых и алевролитов песчанистых, идентичное описанию слоя 5. Песчаники образуют ритмы мощностью от 0.8 до 1.5 м, алевролиты мощностью от 0.4 до 0.6 м. Контакт с нижележащим слоем четкий, переход постепенный. Мощность пачки 5.75 м.

8. Песчаники, идентичные описанным в слое 4. Характерно наличие глинистого цемента. Контакт с нижележащим слоем четкий, эрозионный. Мощность пачки $11.0 \mathrm{м}$.

9. Песчаники, идентичные описанным в слое 6. Известковый цемент отсутствует. Контакт с нижележащим слоем четкий, эрозионный. Мощность пачки 5.25 м.

10. Песчаники, идентичные описанным в слое 2. Известковый цемент отсутствует. Контакт с нижележащим слоем четкий, эрозионный. Мощность пачки 5.5 м.

11. Песчаники буровато-серые, среднезернистые, с глинистым цементом, с восходящей рябью течений. Контакт с нижележащим слоем четкий, переход постепенный. Мощность пачки 3.5 м.

12. Алевролиты песчанистые, коричневато-серые, с мелкой линзовидно-волнистой слоистостью. Контакт с нижележащим слоем четкий, переход резкий. Мощность пачки $4.0 \mathrm{M}$.

13. Алевролиты песчанистые, коричневато-серые, с тонкой пологой волнистой слоистостью. Контакт с нижележащим слоем четкий, переход постепенный. Мощность пачки 5.25 м.

14. Песчаники буровато-серые, мелкозернистые, слабоизвестковистые, с чередованием косой разнонаправленной и волнистой прерывистой слоистости в нижней части и с текстурами гравитационных оползаний и восходящей рябью течений в верхней части слоя, с угловато-окатанными интракластами алевролита размером от $0.2 \times 0.5$ см до $1.0 \times 1.0$ см. Контакт с нижележащим слоем четкий, эрозионный. Мощность пачки 4.0 м.

15. Песчаники, идентичные описанным в слое 11. Присутствует слабый известковый цемент. Контакт с нижележащим слоем четкий, переход постепенный. Мощность пачки $2.5 \mathrm{M}$.

16. Песчаники, идентичные описанным в слое 6. Известковый цемент отсутствует. Контакт с нижележащим слоем четкий, эрозионный. Мощность пачки 3.25 м.

17. Песчаники буровато-серые, мелкозернистые, с чередованием косой разнонаправленной и волнистой прерывистой слоистости в нижней части и с текстурами гравитационных оползаний в верхней части слоя, с угловато-окатанными интракластами алевролита размером от $0.4 \times 0.7$ до $1.0 \times 1.5$ см. Контакт с нижележащим слоем четкий, эрозионный. Мощность пачки 3.25 м.

18. Песчаники, идентичные описанным в слое 11. Присутствует известковый и глинистый цемент. Контакт с нижележащим слоем четкий, переход постепенный. Мощность пачки 2.0 м.

19. Песчаники красновато-серые, грубозернистые, слабоизвестковистые, с крупной косой однонаправленной слоистостью. Отмечаются редкие окатанные обломки метаморфических пород размером от 0.9 до 2.5 см и угловато-окатанные интракласты алевролита размером от $0.5 \times 1.8$ до $3.0 \times 3.5$ см. Контакт с нижележащим слоем четкий, эрозионный. Мощность пачки 1.25 м.

20. Песчаники красновато-серые, крупнозернистые, известковистые, с косой однонаправленной слоистостью, в верхней части слоя с текстурами гравитационного оползания и угловато-окатанными интракластами алевролита размером от $0.5 \times 0.8$ до $1.8 \times 2.0 \mathrm{~cm}$. Контакт с нижележащим слоем четкий, эрозионный. Мощность пачки 2.0 м.

21. Алевролиты песчанистые, коричневато-серые, известковистые, с мелкой линзовидно-волнистой слоистостью, в верхней части слоя наблюдается тонкая, пологоволнистая слоистость. Контакт с нижележащим слоем четкий, переход быстрый. Мощность пачки 2.5 м.

22. Песчаники буровато-серые, мелкозернистые, известковистые, с косой разнонаправленной слоистостью. Контакт с нижележащим слоем четкий, эрозионный. Мощность пачки $2.25 \mathrm{M}$.

23. Алевролиты песчанистые, коричневато-серые, сильно известковистые, с мелкой линзовидно-волнистой слоистостью. Контакт с нижележащим слоем четкий, переход быстрый. Мощность пачки 2.25 м.

24. Алевролиты глинистые, темно-коричневато-серые, известковистые, тонкослоистые. Контакт с нижележащим слоем четкий, переход быстрый. Мощность пачки $1.75 \mathrm{~m}$.

25. Алевролиты песчанистые, коричневато-серые, известковистые, с тонкой субгоризонтальной и пологой слоистостью. Контакт с нижележащим слоем четкий, переход постепенный. Мощность пачки 1.25 м.

26. Доломиты светло-серые, серые, кристаллические, с примесью мелкозернистого песчаного материала, тонкослоистые, плитчатые. Контакт с нижележащим слоем четкий, переход быстрый. Мощность пачки $1.25 \mathrm{M.}$

27. Песчаники светло-буровато-серые, известковистые, с мелкой косой слоистостью ряби течений. Контакт с нижележащим слоем четкий, эрозионный. Мощность пачки $1.5 \mathrm{M}$.

28. Алевролиты песчанистые, идентичные описанным в слое 25. Контакт с нижележащим слоем четкий, переход постепенный. Мощность пачки 1.75 м.

29. Алевролиты глинистые, идентичные описанным в слое 24. Контакт с нижележащим слоем четкий, переход постепенный. Мощность пачки 2.5 м.

30. Доломитовая щебеночная брекчия светло-серого и коричневато-светло-серого цвета, с глинистокарбонатным матриксом. Размер обломков от 1.0 до 20.0 см. Контакт с нижележащим слоем четкий, эрозионный. Мощность пачки 9.0 м.

31. Доломиты светло-серые и серые, тонкокристаллические, от неясно- до тонкослоистых, на границе напластования наблюдаются стилолиты. Контакт с нижележащим слоем четкий, переход постепенный. Мощность пачки $9.0 \mathrm{M.}$

32. Доломиты серые, тонкокристаллические, среднеслоистые, прослоями строматолитовые, микро- и 
тонковолнисто-слоистые. Контакт с нижележащим слоем четкий, переход постепенный. Мощность пачки $6.5 \mathrm{M}$.

\section{5. ГЕНЕТИЧЕСКИЕ КОМПЛЕКСЫ ОТЛОЖЕНИЙ}

Литолого-фациальный анализ пород, изученных в разрезе, позволил выделить переходные и мелководно-морские фации, а именно было установлено, что изученные терригенные породы накапливались в условиях дельты приливно-отливного типа, а карбонатные породы - в мелководно-морских литоральных условиях. Последовательность смены фаций в разрезе показана на рис. 3. В табл. 1 приведена схема фациального расчленения разреза с описанием основных литогенетических типов пород (ЛТ). Фотографии образцов основных ЛТ приведены на рис. 4. Нижняя часть разреза «Шаманский утес», в интервале пачек 1-29, представлена отложениями шаманской свиты, которые формировались в условиях приливно-отливного побережья. Происходило постепенное повышение уровня моря, что отражается в углублении фаций снизу вверх. Авторы предполагают, что в конце формирования шаманской свиты в изучаемом районе существовали мелководноморские условия осадконакопления и формировались карбонаты. При переходе к следующему этапу осадконакопления эти карбонаты были выведены в условия субаэральной экспозиции. Фиксируется стратиграфический перерыв (пачка 30). Иркутский этап начался с карбонатного мелководно-морского осадконакопления.

\section{6. ЛИТОХИМИЧЕСКАЯ ХАРАКТЕРИСТИКА}

Содержания петрогенных оксидов в проанализированных образцах пород, рассчитанные значения петрохимических модулей и формулы их расчетов приведены в Прил. 1. Изученные породы разреза «Шаманский утес» представлены разнозернистыми песчаниками, слагающими пачки № 1-22, 28, 29, 31, песчанистыми доломитами, отмеченными в пачках № $2,4,14,18,19$, $21,23-25,27-29$, а также доломитами (пачки № 20, 23, $24,26,32$ ) (лаб. номера проб см. в Прил. 1). Разнозернистые песчаники обнаруживают концентрации $\mathrm{SiO}_{2}$, варьирующиеся от 78.36 до 82.36 мас. \% и $\mathrm{Al}_{2} \mathrm{O}_{3}$ от 6.48 до 13.74 мас. \% (Прил. 1). Отношение $\mathrm{SiO}_{2} / \mathrm{Al}_{2} \mathrm{O}_{3}$ в этих породах изменяется от 4.33 до 12.27 мас. \%. Для этих пород характерно преобладание $\mathrm{K}_{2} \mathrm{O}$ (2.00-12.51 мас. \%) над $\mathrm{Na}_{2} \mathrm{O}$ (0.11-0.86 мас. \%), при этом значения $\mathrm{K}_{2} \mathrm{O} / \mathrm{Na}_{2} \mathrm{O}$ варьируются от 3.2 до 12.51. Большинство исследованных образцов характеризуются повышенной магнезиальностью (MgO=2.18-6.99 мас. \%), при этом отмечается отсутствие корреляции с СаO (0.24-3.07 мас. \%), что свидетельствует о наличии высокомагнезиальных минералов в обломочной составляющей этих песчаников (Прил. 1). Согласно классификации Ф.Дж. Петтиджона [Pettijohn et al., 1976], все песчаники этой группы обнаруживают преимущественно аркозовый состав (рис. 5), однако часть точек составов попадает в поле пород, для которых характерны аномально низкие содержания $\mathrm{Na}_{2} \mathrm{O}$ и отношение $\log \left(\mathrm{Na}_{2} \mathrm{O} / \mathrm{K}_{2} \mathrm{O}\right)<-1$, что свидетельствует о возможной потере $\mathrm{Na}$ в процессе

Таблица 1. Обстановки осадконакопления терригенно-карбонатных пород мотской серии, разрез «Шаманский утес» Table 1. Sedimentation environment of the terrigenous-carbonate rocks in the Shaman Cliff cross-section (Moty group)

\begin{tabular}{|c|c|c|c|}
\hline $\begin{array}{l}\text { Обста- } \\
\text { новка } \\
\text { седимен- } \\
\text { тации }\end{array}$ & $\begin{array}{l}\text { Макро- } \\
\text { фации }\end{array}$ & Фации & Литогенетические типы \\
\hline 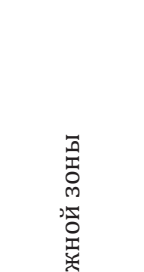 & 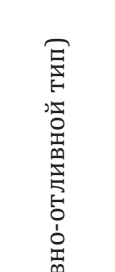 & $\begin{array}{l}\text { Распределительный канал } \\
\text { (с влиянием приливно- } \\
\text { отливных течений) }\end{array}$ & $\begin{array}{l}\text { Песчаники преимущественно крупно- и грубозернистые с прослоями и } \\
\text { примесью мелкого гравийного материала, с косой разнонаправленной и } \\
\text { срезанной слоистостью (см. рис. 4, а) } \\
\text { Песчаники мелкозернистые с косой слоистостью, с восходящей рябью } \\
\text { течений, как однонаправленной, так и разнонаправленной, отдельные } \\
\text { прослои обогащены интракластами аргиллитов, ориентированными } \\
\text { преимущественно согласно напластованию (см. рис. 4, б-г) }\end{array}$ \\
\hline 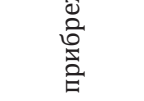 & 岂 & Пески разливов & $\begin{array}{l}\text { Песчаники от мелко- до среднезернистых, часто с прослоями алевролитов, с } \\
\text { восходящей косой слойчатостью ряби течения (см. рис. 4, д) }\end{array}$ \\
\hline 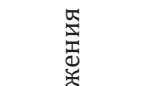 & 营 & Межканальные участки & $\begin{array}{l}\text { Алевролиты и алевролиты песчанистые, с волнисто-линзовидной и } \\
\text { субгоризонтальной слоистостью (см. рис. 4, е, ж) }\end{array}$ \\
\hline$\stackrel{0}{5}$ & 官 & Продельта & $\begin{array}{l}\text { Алевролиты глинистые, микротонкослоистые, участками с конволютной } \\
\text { слоистостью, с тонкими прослоями песчаников (см. рис. 4, 3) }\end{array}$ \\
\hline \multicolumn{2}{|c|}{ Элювиальные } & Субаэральная равнина & Карбонатные элювиальные брекчии (см. рис. 4, и-к) \\
\hline \multirow{3}{*}{ 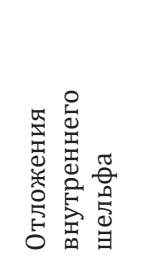 } & \multirow{3}{*}{ 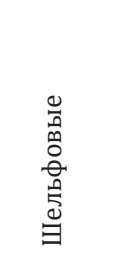 } & $\begin{array}{l}\text { Супралитораль (крайнее мелководье, } \\
\text { себха) }\end{array}$ & $\begin{array}{l}\text { Доломиты глинистые, кристаллические, с реликтовыми порами } \\
\text { выщелоченного ангидрита (см. рис. 4, м) }\end{array}$ \\
\hline & & \multirow{2}{*}{ Литораль верхняя } & $\begin{array}{l}\text { Доломиты разнокристаллические, с несохранившейся первичной } \\
\text { структурой }\end{array}$ \\
\hline & & & $\begin{array}{l}\text { Доломиты тонкокристаллические, строматолитовые (слоистые формы) (см. } \\
\text { рис. } 4, \text { л) }\end{array}$ \\
\hline
\end{tabular}



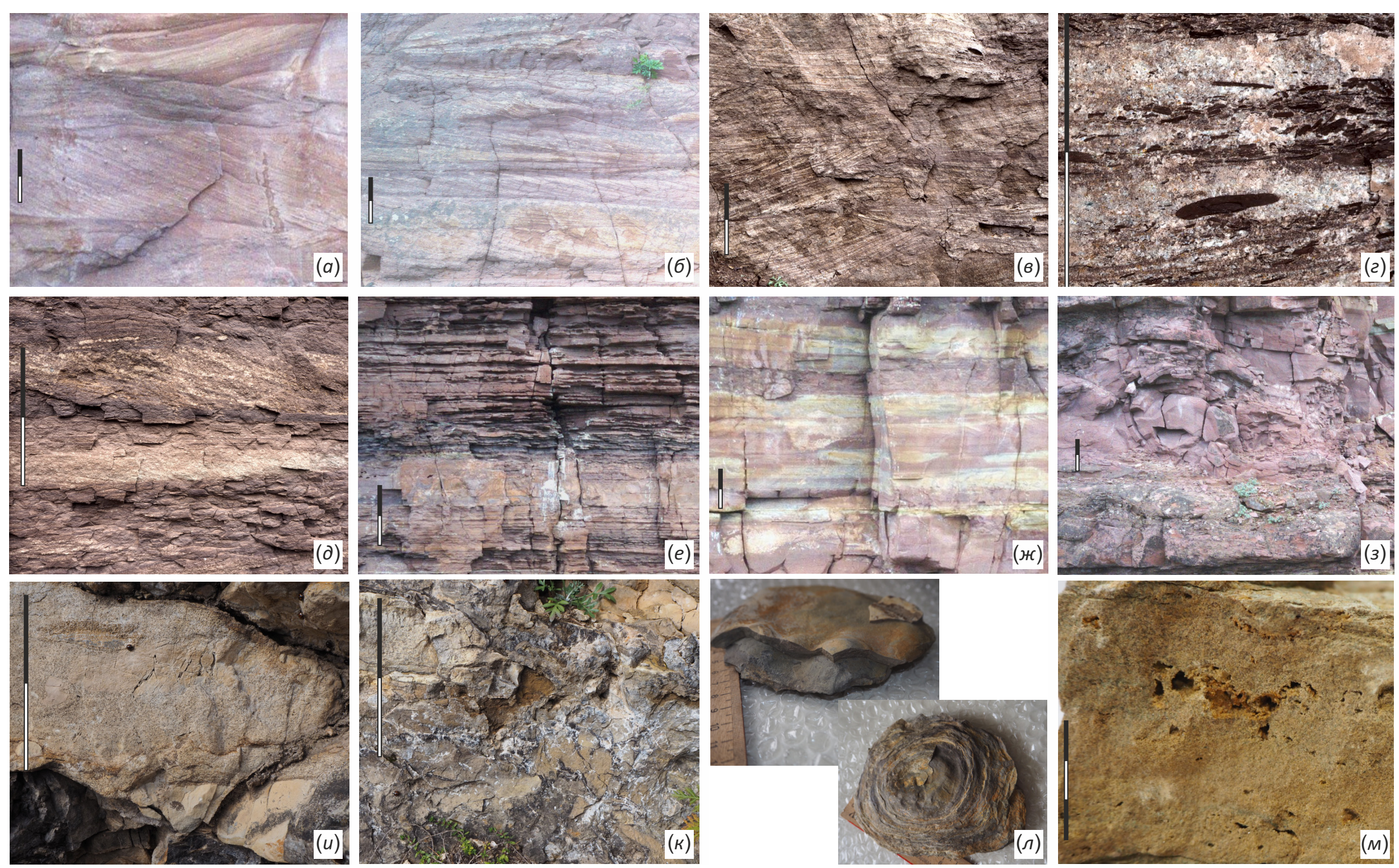
Рис. 4. Характерные литотипы пород мотской серии в разрезе «Шаманский утес».

$(a)$ - песчаники крупно- и грубозернистые с косой разнонаправленной и срезанной слоистостью (распределительные каналы); (б) - песчаники мелкозернистые с мелкой косой, однонаправленной и разнонаправленной слоистостью (приливно-отливные каналы); (в) - песчаники мелкозернистые с мелкой косой разнонаправленной слоистостью (приливно-отливные каналы); (2) - песчаники мелкозернистые с интракластами алевролитов, ориентированных по напластованию (приливно-отливные каналы); (d) - песчаники мелкозернистые с восходящей косой слойчатостью ряби течения (пески разливов); $(e)$ - алевролиты песчанистые с волнисто-линзовидной и субгоризонтальной слоистостью (межканальные участки); (ж) - алевролиты желтовато-серые и алевролиты песчанистые коричневато-серые с субгоризонтальной слоистостью (межканальные участки); (3) - алевролиты глинистые с конволютной слоистостью (продельта); $(u)$ - карбонатная грубообломочная щебенчатая брекчия с глинисто-песчано-карбонатным матриксом (элювиальный горизонт, субаэральная равнина); (к) - карбонатная грубообломочная щебенчатая брекчия (элювиальный горизонт, субаэральная равнина); ( $)$ - доломиты тонкокристаллические строматолитовые (литораль верхняя); (M) - доломиты тонкокристаллические с кавернами выщелачивания (крайнее мелководье, супралитораль). Масштабная линейка на фрагментах (a-8) составляет 1 м; на (2) - 2 см; на (d-к) - 20 см; на (м) - 3 см.

Fig. 4. Lithogenetic types of the Shaman Cliff rocks.

(a) - coarse and coarse-grained sandstones with oblique multidirectional and cut bedding (distribution channels); ( $\sigma$ ) - fine-grained sandstones with fine oblique, unidirectional and multidirectional bedding (tidal channels); ( 8 ) - fine-grained sandstones with fine oblique multidirectional layering (tidal channels); (2) - fine-grained sandstones with siltstone intraclasts oriented along bedding (tidal channels); $(\partial)$ - fine-grained sandstones with ascending oblique bedding of ripples of the current (floodplain sands); $(e)$ - sandy siltstones with wavy-lenticular and subhorizontal bedding (interchannel areas); ( ) - yellowish-gray siltstones and brownish-gray sandy siltstones with subhorizontal bedding (interchannel areas); (3) - clayey siltstones with convolute bedding (prodelta); $(u)$ - carbonate coarse-detrital crushed stone breccia with a clay-sand-carbonate matrix (eluvial horizon, subaerial plain); $(\kappa)$ - carbonate coarse detrital crushed breccia (eluvial horizon, subaerial plain); $(\Omega)$ - fine-crystalline stromatolite dolomite (upper littoral); $(M)$ - fine-crystalline dolomite with leaching caverns (extreme shallow water, supralittoral). Scale bars: $(a-\beta)-1 \mathrm{~m},(2)-2 \mathrm{~cm},(\partial-\kappa)-20 \mathrm{~cm},(\mathcal{M})-3 \mathrm{~cm}$.

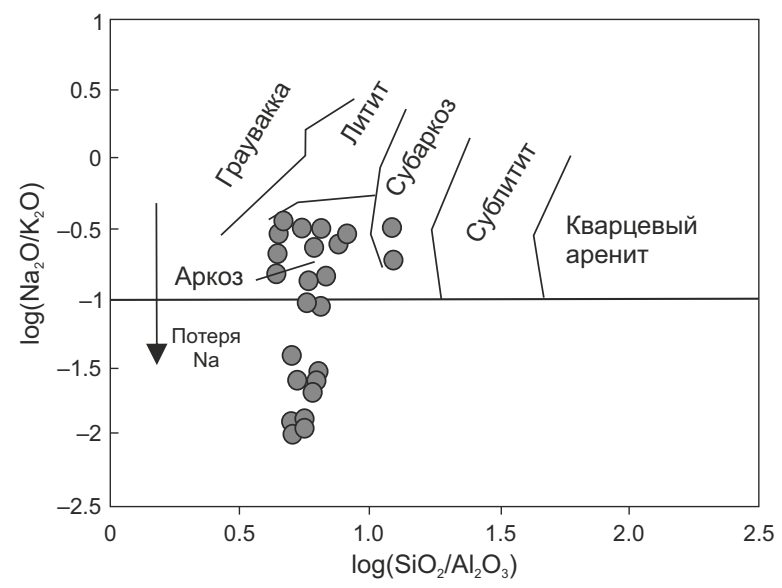

Рис. 5. Классификационная диаграмма $\log \left(\mathrm{Na}_{2} \mathrm{O} / \mathrm{K}_{2} \mathrm{O}\right)-\log \left(\mathrm{SiO}_{2} / \mathrm{Al}_{2} \mathrm{O}_{3}\right)$ [Pettijohn et al., 1976] для терригенных пород мотской серии.

Fig. 5. Classification diagram $\log \left(\mathrm{Na}_{2} \mathrm{O} / \mathrm{K}_{2} \mathrm{O}\right)-\log \left(\mathrm{SiO}_{2} / \mathrm{Al}_{2} \mathrm{O}_{3}\right)$ [Pettijohn et al., 1976] for the terrigenous rocks of the Moty group.
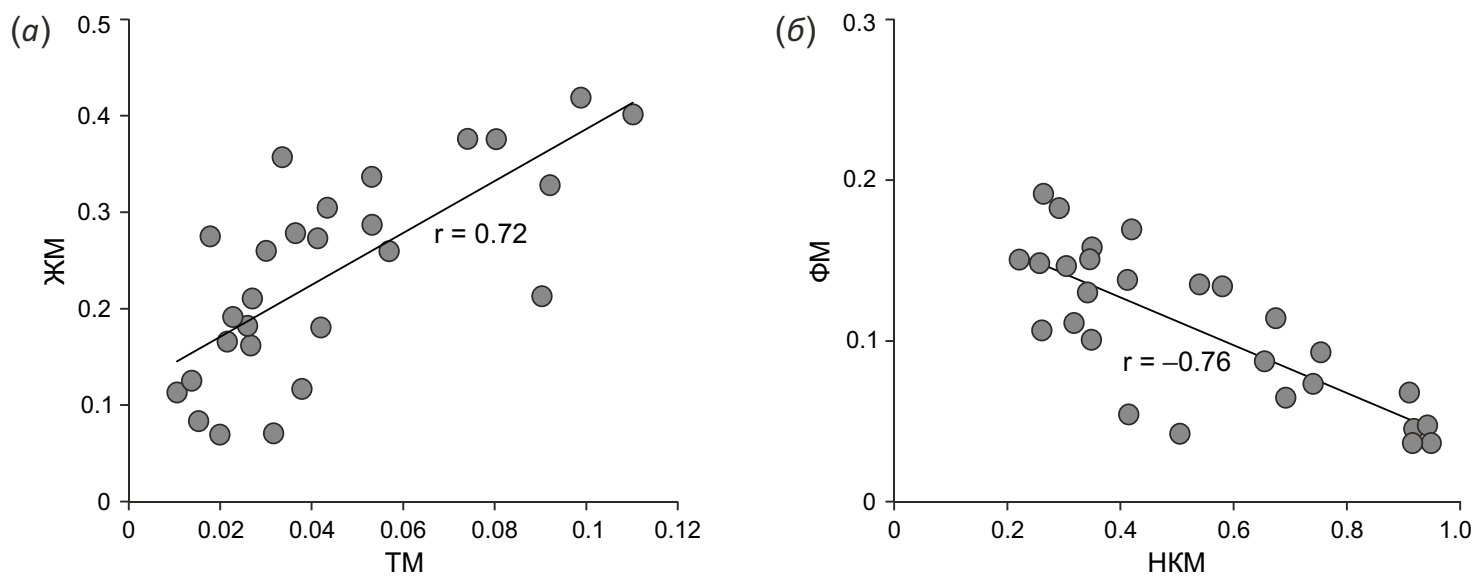

Рис. 6. Модульные диаграммы ЖМ-ТМ, ФМ-НКМ для терригенных пород мотской серии.

Fig. 6. Modular diagrams (ЖМ-ТМ, ФМ-НКМ) for the terrigenous rocks of the Moty group. 

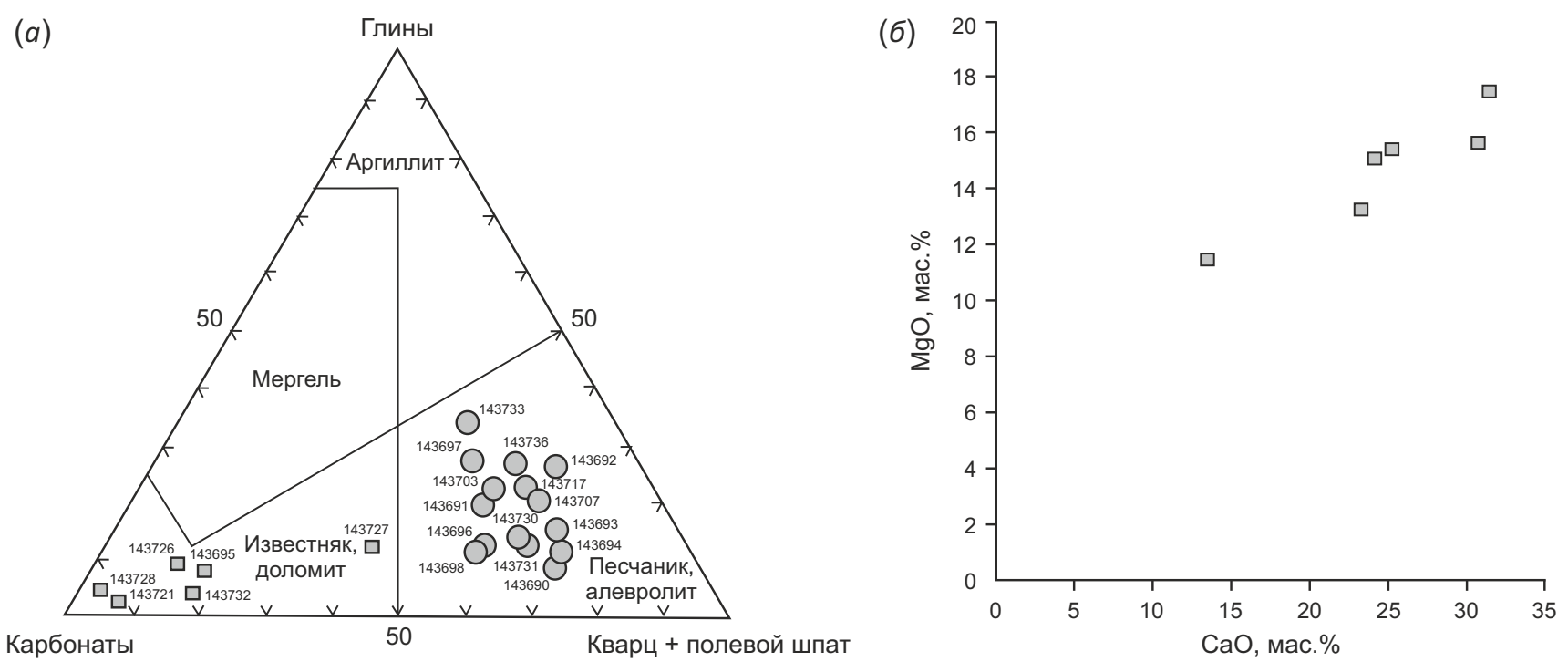

Рис. 7. Диаграмма Карбонаты - Глины - Кварц+полевой шпат [Yudovich, Ketris, 2000] (a) для карбонатных пород мотской серии (диаграмма построена по нормативному минеральному составу, рассчитанному с помощью программы MINLITH [Rosen et al., 2000]) и диаграмма MgO-CaO (б) - для доломитов мотской серии.

Fig. 7. Carbonate - clay - quartz + feldspar diagram [Yudovich, Ketris, 2000] (a) for the carbonate rocks of the Moty group. The diagram is constructed for the standard mineral composition calculated using the MINLITH software [Rosen et al., 2000]). MgO-CaO diagram (б) for the dolomites of the Moty Group.

эпигенетических преобразований. Рассчитанные значения гидролизатного модуля (ГМ) для исследованных пород изменяются от 0.10 до 0.33 , что в соответствии с классификацией по [Yudovich, Ketris, 2000] позволяет отнести образцы, концентрации $\mathrm{MgO}$ для которых не превышают 3 мас. \%, а значения ГМ варьируются от 0.10 до 0.18, к силитам. Образцы с содержанием $\mathrm{MgO}>3$ мас. \% и значениями ГМ=0.10-0.30 могут быть отнесены к группе псевдосилитов. Два образца со значениями ГМ=31-33 и $\mathrm{MgO} 6.99$ и 6.16 мас. \% соответственно (Прил. 1) классифицируются как псевдосиаллиты [Yudovich, Ketris, 2000]. Породы, значения ГМ для которых составляют 0.19-0.23, а сумма щелочей $>8$ мас. \%, $\left(\mathrm{Na}_{2} \mathrm{O}+\mathrm{K}_{2} \mathrm{O}=8.31-12.64\right.$ мас. \%), относятся к алкалитам. Для всех проанализированных песчаников характерно наличие положительной корреляции между железным и титановым модулями (ЖМ-ТМ ( $\mathrm{r}=0.72))$ и отрицательная корреляция между фемическим и модулем нормированной щелочности (ФМ-НКМ ( $\mathrm{r}=-0.76))$ (рис. 6, a, б), что свидетельствует о петрогенной природе этих терригенных пород [Yudovich, Ketris, 2000].

Песчанистые доломиты обнаруживают концентрации $\mathrm{SiO}_{2}$, варьирующиеся от 48.53 до 63.39 мас. \%, а также повышенные значения СаO (3.93 - 9.82 мас. \%) и $\mathrm{MgO}$ (3.93-9.22 мас. \%). Содержания $\mathrm{Al}_{2} \mathrm{O}_{3}$ в этих породах варьируются от 8.54 до 11.61 мас. $\%, \mathrm{TiO}_{2}$ - от 0.30 до 0.85 мас. \% (Прил. 1). Для карбонатных пород был рассчитан нормативный минеральный состав с использованием программы MINLITH [Rosen et al., 2000]. Количественное соотношение нормативных минералов указывает на то, что эти породы относятся к группе терригенных пород, а именно к карбонатным песчаникам и алевролитам (рис. 7, a). В усредненном нормативном минеральном составе этих пород преобладает кварц (22-47 \%), полевые шпаты (8-39 \%) и глинистые минералы (7-26 \%), представленные иллитом и серпентином. Карбонатные минералы в основном представлены доломитом (12-32 \%) (Прил. 1).

Изученные доломиты характеризуются низкими содержаниями $\mathrm{SiO}_{2}$ (3.21-33.0 мас. \%), а также высокими содержаниями $\mathrm{CaO}$ (13.67-31.22 мас. \%) и $\mathrm{MgO}$ (11.37-17.26 мас. \%), при этом отмечается положительная корреляция между $\mathrm{CaO}$ и $\mathrm{MgO}$ (рис. 7, б), что свидетельствует о преобладании доломита в составе этих пород. Концентрации $\mathrm{Al}_{2} \mathrm{O}_{3}$ варьируются от 1.22 до 8.22 мас. \% и могут указывать на примесный характер глинистых минералов. Содержания $\mathrm{Fe}_{2} \mathrm{O}_{\text {зобщ }}$ coставляют 1.50-4.65 мас. \%. В нормативном минеральном составе этих пород преобладает доломит (45-79 \%), при этом отмечается небольшое количество кальцита (3-14\%), анкерита (4-12\%), кварца (2-10\%) и полевых шпатов (3-8\%). Глинистые минералы в этих породах в основном представлены иллитом (2-9 \%) (Прил. 1). Таким образом, количественное соотношение нормативных минералов позволяет отнести эти породы к доломитам (рис. 7, a) [Yudovich, Ketris, 2000].

Следует отметить, что количественные соотношения минералов, рассчитанные с помощью программы MINLITH [Rosen et al., 2000], в изученных терригенно-карбонатных породах подтверждают данные о минеральном составе пород, полученных методом РСА (см. рис. 3).

\section{7. ОБСУЖДЕНИЕ РЕЗУЛЬТАТОВ}

Изучение литохимических характеристик (петрогенные элементы) этих пород позволило более точно 
охарактеризовать их вещественный состав. Анализ концентраций петрогенных оксидов указывает на аркозовый состав терригенных пород нижней части изученного разреза. Генетическая типизация разнозернистых песчаников, проведенная с использованием системы петрохимических модулей [Yudovich, Ketris, 2000], свидетельствует о петрогенной природе (т.е. образовании за счет разрушения первично-магматических пород) изученных разнозернистых песчаников разреза «Шаманский утес». Выявленное постепенное увеличение карбонатной составляющей в вещественном составе пород верхних частей разреза подтверждает предположение предшественников о поздневендской смене приливно-отливного режима бассейна седиментации на мелководно-морской на южной окраине Сибирской платформы.

В результате седиментологических исследований были выделены 32 литологические пачки и восемь литолого-генетических типов пород (см. рис. 3). Применение литолого-фациального анализа для выделенных пачек способствовало определению условий седиментации изученных пород (табл. 1). Было установлено, что изученные породы шаманской свиты накапливались в условиях приливно-отливного побережья. Проградация дельтовой равнины могла происходить на этапе высокого стояния уровня моря, расположенного в дистальной части форландового бассейна, образование которого, вероятно, связано с вендскими орогенными событиями, проявленными в южном складчатом обрамлении Сибирской платформы [Gladkochub et al., 2019, и ссылки в данной работе]. С учетом peзультатов U-Pb (LA-ICP-MS) датирования зерен детритового циркона из терригенно-карбонатных пород иркутской свиты [Marusin et al., 2021], где большинство датировок образуют не характерный для пород фундамента Сибирской платформы [Priyatkina et al., 2016; Donskaya, 2020] возрастной пик на 530 млн лет, можно предположить, что основной снос обломочного материала в этот бассейн седиментации происходил с орогена, возникшего в результате вендских аккреционно-коллизионных событий. Породы выделенных в разрезе пачек 1-23, 27-28 были сформированы в пределах дельтовой равнины. В указанном интервале выделены следующие фации: пески разлива, распределительные каналы (с влиянием приливно-отливных течений), приливно-отливные каналы и межканальные участки. Отложения этого интервала представлены главным образом песчаниками и алевролитами (межканальные участки). Породы выделенных в изученном разрезе пачек 24, 25 и 29 представлены глинистыми алевролитами, сформированными в условиях продельты. Породы, слагающие пачку 26, представлены песчанистыми доломитами, сформированными в седиментационном бассейне за пределами дельты. В интервале пачек 1-23 преобладают отложения фронта дельты. В это время шла ее активная проградация. На завершающем этапе преобладают отложения фронта дельты и шельфа (пачки 24-26, 29), что свидетельствует об уменьшении объемов обломочного материала, поступающего в бассейн седиментации, и преобладании агградации.

Проведение границы между красноцветной терригенной шаманской и светло-серой терригенно-карбонатной иркутской свитами до настоящего времени вызывало затруднение, что связано с постепенным переходом и увеличением доли доломита в терригенно-карбонатных отложениях, сменяющихся выше по разрезу карбонатными породами. Особое внимание авторов вызывает 30-я пачка (см. рис. 3), представленная карбонатными элювиальными брекчиями, которые могут быть интерпретированы как образования, фиксирующие стратиграфический перерыв. По-видимому, в конце шаманского времени в изученном районе имели место мелководно-морские условия с карбонатным осадконакоплением и породы пачек 31 и 32 являются отложениями иркутской свиты. Вывод их в субаэральные условия могли спровоцировать как положительные тектонические движения, так и общее понижение уровня моря, что не противоречит мнению предшественников о наличии вендских аккреционно-коллизионных событий, спровоцировавших перестройку палеогеографии исследуемой территории. Мы предлагаем использовать 30-ю пачку в качестве реперной и провести по ее подошве границу между шаманской и иркутской свитами. Учитывая биостратиграфические данные, приведенные в работе [Marusin et al., 2021], можно считать подошву, выделенную в разрезе «Шаманский утес» 30-й пачки границей верхнего венда и томмотского яруса кембрия. Литолого-фациальные особенности пород иркутской свиты свидетельствуют о спокойном тектоническом режиме осадконакопления, без поступления обломочного материала, что способствовало благоприятным условиям сохранности кембрийской фауны, охарактеризованной в работе [Marusin et al., 2021].

\section{8. ЗАКЛЮЧЕНИЕ}

В результате проведенных исследований можно сделать следующие выводы:

1. Анализ концентраций петрогенных оксидов в изученных терригенных породах мотской серии указывает на их принадлежность к аркозам и на то, что они были образованы за счет накопления продуктов разрушения первично-магматических пород. Выявленное постепенное увеличение содержания карбонатной составляющей в вещественном составе терригенно-карбонатных пород верхних частей разреза «Шаманский утес», вплоть до чистых доломитов, не противоречит выводам предшественников о постепенном отмирании дельты и сокращении объемов обломочного материала, поступающего в осадочный бассейн.

2. В разрезе «Шаманский утес» выделено 32 литологические пачки и восемь литолого-генетических типов пород. Установлено, что породы шаманской свиты накапливались в условиях бассейна приливно-отливного типа. Проградация дельтовой равнины могла 
происходить на этапе высокого стояния уровня моря; при этом предполагается, что основной снос обломочного материала происходил с орогена, возникшего в результате вендских аккреционно-коллизионных событий, известных в южном складчатом обрамлении Сибирской платформы.

3. Доломиты, охарактеризованные в пачках 30, 31 и 32 , принадлежат иркутской свите. Литолого-фациальные особенности этих пород свидетельствуют о мелководно-морских условиях их образования, без поступления обломочного материала, что способствовало сохранности биоты кембрийского возраста, охарактеризованной в работах предшественников.

4. На основе полученных результатов, а также с учетом новых биостратиграфических данных по терригенно-карбонатным породам иркутской свиты [Marusin et al., 2021] граница между шаманской и иркутской свитами проведена по подошве выделенной авторами пачки карбонатной элювиальной брекчии (пачка 30), фиксирующей субаэральный перерыв, и соответствует границе верхнего венда и нижнего кембрия в изученном разрезе.

\section{9. БЛАГОДАРНОСТИ}

Авторы благодарят д.г.-М.н. А.М. Мазукабзова, д.г.м.н. Т.В. Донскую и чл.-корр. РАН Д.П. Гладкочуба за ценные рекомендации, существенно улучшившие качество работы.

\section{0. ЛИТЕРАТУРА / REFERENCES}

Donskaya T.V., 2020. Assembly of the Siberian Craton: Constraints from Paleoproterozoic Granitoids. Precambrian Research 348, 105869. https://doi.org/10.1016/j. precamres.2020.105869.

Gladkochub D.P., Donskaya T.V., Stanevich A.M., Pisarevsky S.A., Zhang S., Motova Z.L., Mazukabzov A.M., Li H., 2019. U-Pb Detrital Zircon Geochronology and Provenance of Neoproterozoic Sedimentary Rocks in Southern Siberia: New Insights into Breakup of Rodinia and Opening of PaleoAsian Ocean. Gondwana Research 65, 1-16. https://doi.org/ 10.1016/j.gr.2018.07.007.

Khomentovsky V.V., Shenfil V.Yu., Yakshin M.S., 1972. Reference Cross-Sections of the Upper Precambrian and Lower Cambrian Deposits of the Southern Margin of the Siberian Platform. Nauka, Moscow, 356 p. (in Russian) [Xoментовский В.В., Шенфиль В.Ю., Якшин М.С. Опорные разрезы отложений верхнего докембрия и нижнего кембрия южной окраины Сибирской платформы. М.: Наука, 1972. 356 с.].

Kuznetsov V.G., 2011. Lithology - Fundamentals of General (Theoretical) Lithology. Nauchny Mir, Moscow, 360 p. (in Russian) [Кузнецов В.Г. Литология - основы общей (теоретической) литологии. М.: Научный мир, 2011. 360 c.].

Makhlaev M.L., 2002. Legend of the Angara-Yenisei Series Sheets of the State Geological Map of the Russian Federation. Scale 1:1000000. Third edition. Krasnoyarsk Geological Survey, Krasnoyarsk (in Russian) [Махлаев М.Л. Легенда
Ангаро-Енисейской серии листов Государственной геологической карты РФ масштаба 1:1000000 (третье издание). Красноярск: Красноярскгеолсъемка, 2002].

Marusin V.V., Kolesnikova A.A., Kochnev B.B., Kuznetsov N.B., Pokrovsky B.G., Romanyuk T.V., Karlova G.A., Rud'ko S.V. et al., 2021. Detrital Zircon Age and Biostratigraphic and Chemostratigraphic Constraints on the Ediacaran-Cambrian Transitional Interval in the Irkutsk Cis-Sayans Uplift, Southwestern Siberian Platform. Geological Magazine 158 (7), 1156-1172. https://doi.org/10.1017/S0016756820 001132.

Maslov A.V., 2005. Sedimentary Rocks: Study Methods and Data Interpretation. Urals State Mining University, Ekaterinburg, 289 р. (in Russian) [Маслов А.В. Осадочные породы: методы изучения и интерпретация полученных данных. Екатеринбург: УГГУ, 2005. 289 с.].

Pettijohn F., Potter P., Siever R., 1976. Sands and Sandstones. Mir, Moscow, 536 p. (in Russian) [Петтиджон Ф., Поттер П., Сивер Р. Пески и песчаники. М.: Мир, 1976. 536 c.].

Priyatkina N.S., Khudoley A.K., Collins W.J., Kuznetsov N.B., Huang H.Q., 2016. Detrital Zircon Record of Meso-and Neoproterozoic Sedimentary Basins in Northern Part of the Siberian Craton: Characterizing Buried Crust of the Basement. Precambrian Research 285, 21-38. https://doi.org/ 10.1016/j.precamres.2016.09.003.

Reinek G.E., Singkh I.B., 1981. Setting of Terrigenous Sedimentation. Nedra, Moscow, 440 p. (in Russian) [Рейнек Г.Э., Сингх И.Б. Обстановки терригенного осадконакопления. М.: Недра, 1981. 440 с.].

Rosen O.M., Abbyasov A.A., Migdisov A.A., Yaroshevskii A.A., 2000. MINLITH - a Program to Calculate the Normative Mineralogy of Sedimentary Rocks: the Reliability of Results Obtained for Deposits of Old Platforms. Geochemistry International 38 (4), 388-400.

Salop L.I., 1964. Geology of the Baikal Mountainous Area. Vol. 1. Nedra, Moscow, 515 p. (in Russian) [Салоп Л.И. Геология Байкальской горной области. М.: Недра, 1964. T. $1.515 \mathrm{c}]$.

Savitsky V.E., Krasnov V.I., Khomentovsky V.V. (Eds), 1983. Decree of the All-Union Stratigraphic Conference on the Precambrian, Paleozoic and Quaternary System of Central Siberia (Novosibirsk, 1979). Part 1: Upper Proterozoic (Upper Precambrian) and Lower Paleozoic. Explanatory Notes. VSEGEI Publishing House, Leningrad, Novosibirsk, 215 p. (in Russian) [Решение Всесоюзного стратиграфического совещания по докембрию, палеозою, четвертичной системе Средней Сибири (Новосибирск, 1979 г.). Ч. 1: Верхний протерозой (верхний докембрий) и нижний палеозой: Объяснительные записки / Ред. В.Е. Савицкий, В.И. Краснов, В.В. Хоментовский. Ленинград, Новосибирск: Изд-во ВСЕГЕИ, 1983. 215 с.].

Selly R.C., 1989. Ancient Sedimentary Environments. Nedra, Moscow, 294 p. (in Russian) [Селли Р.Ч. Древние обстановки осадконакопления. М.: Недра, 1989. 294 с.].

Shabanov Yu.Ya. (Ed.), 2016. Stratigraphy of Siberian Oiland-Gas Basins. Cambrian of the Siberian Platform. Vol. 1. Institute of Petroleum Geology and Geophysics SB RAS, 
Novosibirsk, 497 p. (in Russian) [Стратиграфия нефтегазоносных бассейнов Сибири. Кембрий Сибирской платформы / Ред. Ю.Я. Шабанов. Новосибирск: ИНГГ СО РАН, 2016. T. 1.497 c.].

Shenfil V.Yu., 1991. Late Precambrian of the Siberian Platform. Nauka, Novosibirsk, 183 p. (in Russian) [Шенфиль В.Ю. Поздний докембрий Сибирской платформы. Новосибирск: Наука, 1991. 183 с.].

Sklyarov E.V. (Ed.), 2006. Evolution of the Southern Part of the Siberian Craton. In: Integration Projects of SB RAS. Iss. 11. Publishing House of SB RAS, Novosibirsk, 367 p. (in Russian) [Эволюция южной части Сибирского кратона // Интеграционные проекты СО РАН / Ред. Е.В. Скляров. Новосибирск: Изд-во СО РАН, 2006. Вып. 11. 367 с.].

Sovetov Yu.K., 1977. Upper Precambrian Sandstones of the Southwestern Siberian Platform. Nauka, Novosibirsk, 295 p. (in Russian) [Советов Ю.К. Верхнедокембрийские песчаники юго-запада Сибирской платформы. Новосибирск: Наука, 1977. 295 с.].

Sovetov Yu.K., 2018. Sedimentology and Stratigraphic Correlation of Vendian Deposits in the Southwestern Siberian Platform: Major Contribution of an Exocratonic Clastic Source to Sedimentary Systems. Lithosphere 18 (1), 20-45 (in Russian) [Советов Ю.К. Седиментология и стратиграфическая корреляция вендских отложений на юго-западе Сибирской платформы: выдающийся вклад внешнего источника кластического материала в образование осадочных систем // Литосфера. 2018. Т. 18. № 1. С. 20-45]. https://doi.org/10.24930/1681-9004-2018-18-1-020-045.

Sovetov Yu.K., Blagovidov V.V., 2004. Reconstruction of the Sedimentation Basin (Case of the Vendian Foredeep Foreland Basin of the Southwestern Siberian Platform). In: Yu.G. Leonov, Yu.A. Volozh (Eds), Sedimentary Basins: Study Methods, Structure and Evolution. Nauchny Mir, Moscow, p. 159-212 (in Russian) [Советов Ю.К., Благовидов В.В. Реконструкция бассейна осадконакопления (на примере вендского передового прогиба - «форландового бассейна» юго-запада Сибирской платформы) // Ocадочные бассейны: методы изучения, строение и эволюция / Ред. Ю.Г. Леонов, Ю.А. Волож. М.: Научный мир, 2004. C. 159-212].

Sovetov Yu.K., Kulikova A.E., Medvedev M.N., 2007. Sedimentary Basins in the Southwestern Siberian Craton: Late Neoproterozoic - Early Cambrian Riftng Ad Collisional Events. In: U. Linnemann, R.D. Nance, P. Kraft, G. Zulauf (Eds), The Evolution of the Rheic Ocean: from AvalonianCadomian Active Margin to Alleghenian-Variscan Collision.
Geological Society of America Special Papers 423, 549-578. https://doi.org/10.1130/2007.2423(28).

Stanevich A.M., Mazukabzov A.M., Postnikov A.A., Nemerov V.K., Pisarevsky S.A., Gladkochub D.P., Donskaya T.V., Kornilova T.A., 2007. Northern Segment of the Paleoasian Ocean: Neoproterozoic Deposition History and Geodynamics. Russian Geology and Geophysics 48 (1), 46-60. https: / doi. org/10.1016/j.rgg.2006.12.005.

Stanevich A.M., Nemerov V.K., Chatta E.N., 2006. Proterozoic Microfossils of the Sayan-Baikal Folded Area. Environments, Nature and Classification. GEO, Novosibirsk, 204 p. (in Russian) [Станевич A.М., Немеров В.К., Чатта Е.Н. Микрофоссилии протерозоя Саяно-Байкальской складчатой области. Обстановки обитания, природа и классификация. Новосибирск: Гео, 2006, 204 с.].

State Geological Map of the Russian Federation, 2009. Angara-Yenisei Series. Scale 1:1000000. Sheet N-48 (Irkutsk). Explanatory Note. VSEGEI Publishing House, Saint Petersburg, 574 p. (in Russian) [Государственная геологическая карта Российской Федерации. Серия Ангаро-Енисейская. Масштаб 1:1000000. Лист N-48 (Иркутск): Объяснительная записка. СПб.: Изд-во ВСЕГЕИ, 2009. 574 с.].

State Geological Map of the Russian Federation, 2013. East Sayan Series. Scale 1:200000. Sheet N-48-XXXII. Explanatory Note. Moscow Branch of VSEGEI, Moscow, 186 p. (in Russian) [Государственная геологическая карта Российской Федерации. Серия Восточно-Саянская. Масштаб 1:200000. Лист N-48-XXXII: Объяснительная записка. М.: МФ ВСЕГЕИ, 2013. 186 с.].

Vishnyakov S.G., 1933. Carbonate Rocks and Field Study of Their Suitability for Soil Liming. In: Carbonate Rocks of the Leningrad Region, the Northern Krai and the Karelian Autonomous Soviet Socialist Republic. Iss. 2. Gosgorgeonefteizdat, Moscow, Leningrad, p. 3-22 (in Russian) [Вишняков С.Г. Карбонатные породы и полевое исследование их пригодности для известкования почвы // Карбонатные породы Ленинградской области, Северного края и Карельской АССР. М.-Л.: Госгоргеонефтеиздат, 1933. Вып. 2. С. 3-22].

Yudovich Ya.E., Ketris M.P., 2000. Fundamentals of Lithochemistry. Nauka, Saint Petersburg, 497 p. (in Russian) [Юдович Я.Э., Кетрис М.П. Основы литохимии. СПб.: Наука, 2000. 497 c.].

Zhamoyda A.I. (Ed.), 2019. Stratigraphic Code of Russia. VSEGEI Publishing House, Saint Petersburg, 92 p. (in Russian] [Стратиграфический кодекс России / Ред. А.И. Жамойда. СПб.: Изд-во ВСЕГЕИ, 2019. 92 с.]. 


\section{ПРИЛОЖЕНИЕ 1 / APPENDIX 1}

Таблица 1. Литохимический состав терригенно-карбонатных пород мотской серии в разрезе «Шаманский утес»

Table 1. Lithochemical composition of the terrigenous-carbonate rocks in the Shaman Cliff cross-section (Moty group)

\begin{tabular}{|c|c|c|c|c|c|c|c|c|c|c|c|c|c|c|c|c|}
\hline \multirow{3}{*}{ Компонент } & пачка 1 & \multicolumn{2}{|c|}{ пачка 2} & пачка 3 & пачка 4 & пачка 5 & пачка 6 & пачка 7 & пачка 8 & пачка 9 & пачка 10 & пач & a 11 & пачка 12 & пачка 13 & пачка 14 \\
\hline & \multicolumn{16}{|c|}{ № пробы лабораторный } \\
\hline & $143720^{1}$ & $143719^{1}$ & $143736^{2}$ & $143718^{1}$ & $143717^{2}$ & $143716^{1}$ & $143715^{1}$ & $143714^{1}$ & $143713^{1}$ & $143712^{1}$ & $143711^{1}$ & $143710^{1}$ & $143735^{1}$ & $143709^{1}$ & $143708^{1}$ & $143707^{2}$ \\
\hline $\mathrm{SiO}_{2}$, мас. $\%$ & 71.66 & 78.36 & 61.42 & 61.95 & 63.39 & 65.49 & 70.83 & 65.53 & 67.44 & 74.08 & 82.36 & 63.20 & 70.81 & 63.47 & 63.20 & 57.93 \\
\hline $\mathrm{TiO}_{2}$ & 0.32 & 0.14 & 0.65 & 1.12 & 0.43 & 1.11 & 0.33 & 0.45 & 1.11 & 0.56 & 0.16 & 0.62 & 1.04 & 1.31 & 0.26 & 0.50 \\
\hline $\mathrm{Al}_{2} \mathrm{O}_{3}$ & 11.82 & 6.48 & 8.77 & 13.94 & 8.54 & 12.05 & 9.05 & 10.88 & 10.07 & 9.83 & 6.71 & 14.28 & 10.52 & 14.50 & 14.59 & 10.79 \\
\hline $\mathrm{Fe}_{2} \mathrm{O}_{\text {зобщ }}$ & 2.54 & 1.07 & 3.48 & 5.63 & 2.36 & 4.28 & 2.57 & 3.05 & 4.45 & 2.68 & 1.27 & 4.52 & 4.82 & 3.35 & 4.06 & 4.54 \\
\hline $\mathrm{MnO}$ & 0.01 & 0.03 & 0.06 & 0.03 & 0.08 & 0.03 & 0.04 & 0.04 & 0.04 & 0.02 & 0.01 & 0.02 & 0.02 & 0.01 & 0.02 & 0.06 \\
\hline $\mathrm{MgO}$ & 5.39 & 3.14 & 6.16 & 6.16 & 5.47 & 5.26 & 4.51 & 5.42 & 5.50 & 5.17 & 2.18 & 6.99 & 5.80 & 6.19 & 6.60 & 5.29 \\
\hline $\mathrm{CaO}$ & 0.40 & 2.40 & 5.43 & 1.36 & 5.94 & 1.78 & 2.82 & 3.07 & 1.97 & 0.39 & 0.35 & 0.43 & 0.46 & 0.72 & 0.24 & 5.67 \\
\hline $\mathrm{Na}_{2} \mathrm{O}$ & 0.70 & 0.65 & 0.54 & 1.01 & 0.87 & 0.88 & 0.67 & 0.69 & 0.59 & 0.50 & 0.53 & 0.93 & 0.29 & 0.86 & 0.79 & 0.50 \\
\hline $\mathrm{K}_{2} \mathrm{O}$ & 3.06 & 2.04 & 2.53 & 2.67 & 2.17 & 2.79 & 2.49 & 3.03 & 2.00 & 2.07 & 2.86 & 3.24 & 2.04 & 4.16 & 5.34 & 5.48 \\
\hline $\mathrm{P}_{2} \mathrm{O}_{5}$ & 0.09 & 0.06 & 0.07 & 0.12 & 0.07 & 0.10 & 0.06 & 0.08 & 0.11 & 0.10 & 0.07 & 0.15 & 0.12 & 0.43 & 0.05 & 0.18 \\
\hline п.п.п. & 3.80 & 5.03 & 10.59 & 5.79 & 10.48 & 5.85 & 6.26 & 7.55 & 6.48 & 4.36 & 2.55 & 5.37 & 3.82 & 4.74 & 4.61 & 8.78 \\
\hline Сумма & 99.79 & 99.50 & 99.80 & 99.78 & 99.80 & 99.65 & 99.67 & 99.79 & 99.76 & 99.78 & 99.24 & 99.81 & 99.78 & 99.76 & 99.80 & 99.77 \\
\hline $\mathrm{SiO}_{2} / \mathrm{Al}_{2} \mathrm{O}_{3}$ & 6.06 & 12.09 & 7.00 & 4.44 & 7.42 & 5.43 & 7.83 & 6.02 & 6.70 & 7.54 & 12.27 & 4.43 & 6.73 & 4.38 & 4.33 & 5.37 \\
\hline $\mathrm{K}_{2} \mathrm{O} / \mathrm{Na}_{2} \mathrm{O}$ & 4.37 & 3.14 & 4.69 & 2.64 & 2.49 & 3.17 & 3.72 & 4.39 & 3.39 & 4.14 & 5.40 & 3.48 & 7.03 & 4.84 & 6.76 & 10.96 \\
\hline $\mathrm{K}_{2} \mathrm{O}+\mathrm{Na}_{2} \mathrm{O}$ & 3.76 & 2.69 & 3.07 & 3.68 & 3.04 & 3.67 & 3.16 & 3.72 & 2.59 & 2.57 & 3.39 & 4.17 & 2.33 & 5.02 & 6.13 & 5.98 \\
\hline ГМ & 0.21 & 0.10 & - & 0.33 & - & 0.27 & 0.17 & 0.22 & 0.23 & 0.18 & 0.10 & 0.31 & 0.23 & 0.30 & 0.30 & 0.27 \\
\hline $\mathrm{TM}$ & 0.03 & 0.02 & - & 0.08 & - & 0.09 & 0.04 & 0.04 & 0.11 & 0.06 & 0.02 & 0.04 & 0.10 & 0.09 & 0.02 & 0.05 \\
\hline НКМ & 0.32 & 0.42 & - & 0.26 & - & 0.30 & 0.35 & 0.34 & 0.26 & 0.26 & 0.51 & 0.29 & 0.22 & 0.35 & 0.42 & 0.55 \\
\hline ЖМ & 0.21 & 0.17 & - & 0.38 & - & 0.33 & 0.28 & 0.27 & 0.40 & 0.26 & 0.19 & 0.30 & 0.42 & 0.21 & 0.27 & 0.41 \\
\hline$\Phi \mathrm{M}$ & 0.11 & 0.05 & - & 0.19 & - & 0.15 & 0.10 & 0.13 & 0.15 & 0.11 & 0.04 & 0.18 & 0.15 & 0.15 & 0.17 & 0.17 \\
\hline Плагиоклаз, \% & - & - & 5 & - & 8 & - & - & - & - & - & - & - & - & - & & - \\
\hline Ортоклаз & - & - & 3 & - & 2 & - & - & - & - & - & - & - & - & - & - & - \\
\hline Кварц & - & - & 45 & - & 47 & - & - & - & - & - & - & - & - & - & - & - \\
\hline Иллит & - & - & 22 & - & 20 & - & - & - & - & - & - & - & - & - & - & - \\
\hline Анкерит & - & - & 0 & - & 0 & - & - & - & - & - & - & - & - & - & - & - \\
\hline Серпентин & - & - & 4 & - & 2 & - & - & - & - & - & - & - & - & - & - & - \\
\hline Кальцит & - & - & 0 & - & 0 & - & - & - & - & - & - & - & - & - & - & - \\
\hline Доломит & - & - & 17 & 19 & - & - & - & - & - & - & & & & - & - & - \\
\hline
\end{tabular}


Таблица 1. (продолжение)

Table 1. (continued)

\begin{tabular}{|c|c|c|c|c|c|c|c|c|c|c|c|c|c|c|c|c|}
\hline \multirow{3}{*}{ Компонент } & пачка 14 & пачка 15 & пачка 16 & пачка 17 & пачка 18 & \multicolumn{2}{|c|}{ пачка 19} & пач & 20 & \multicolumn{3}{|c|}{ пачка 21} & \multicolumn{2}{|c|}{ пачка 22} & \multicolumn{2}{|c|}{ пачка 23} \\
\hline & \multicolumn{16}{|c|}{ № пробы лабораторный } \\
\hline & $143734^{1}$ & $143706^{1}$ & $143705^{1}$ & $143704^{1}$ & $143703^{2}$ & $143702^{1}$ & $143733^{2}$ & $143701^{1}$ & $143732^{3}$ & $143700^{1}$ & $143730^{2}$ & $143731^{2}$ & $143699^{1}$ & $143729^{1}$ & $143728^{3}$ & $143698^{2}$ \\
\hline $\mathrm{SiO}_{2}$, мac. $\%$ & 67.25 & 65.42 & 67.71 & 65.70 & 52.13 & 64.09 & 51.43 & 70.65 & 14.97 & 65.96 & 51.80 & 58.12 & 67.40 & 66.96 & 3.21 & 46.83 \\
\hline $\mathrm{TiO}_{2}$ & 0.62 & 0.13 & 0.40 & 0.14 & 0.39 & 0.32 & 0.63 & 0.30 & 0.20 & 0.33 & 0.49 & 0.63 & 0.60 & 0.24 & 0.07 & 0.48 \\
\hline $\mathrm{Al}_{2} \mathrm{O}_{3}$ & 11.66 & 10.17 & 11.91 & 13.22 & 10.09 & 12.29 & 11.52 & 11.22 & 3.63 & 10.97 & 10.10 & 10.50 & 11.27 & 12.02 & 1.22 & 8.86 \\
\hline $\mathrm{Fe}_{2} \mathrm{O}_{306 щ}$ & 4.11 & 1.22 & 4.37 & 1.49 & 3.43 & 2.27 & 4.44 & 1.84 & 2.12 & 2.88 & 3.12 & 2.05 & 3.38 & 0.84 & 1.50 & 2.94 \\
\hline $\mathrm{MnO}$ & 0.02 & 0.02 & 0.02 & 0.02 & 0.14 & 0.02 & 0.15 & 0.02 & 0.08 & 0.06 & 0.07 & 0.04 & 0.02 & 0.01 & 0.10 & 0.21 \\
\hline MgO & 5.12 & 2.98 & 4.74 & 4.20 & 8.06 & 3.64 & 8.09 & 3.30 & 15.17 & 4.57 & 6.90 & 3.93 & 5.60 & 2.24 & 17.26 & 8.34 \\
\hline $\mathrm{CaO}$ & 1.14 & 2.44 & 0.33 & 2.07 & 7.36 & 2.78 & 6.40 & 0.55 & 24.79 & 2.79 & 7.35 & 8.71 & 1.24 & 1.88 & 31.22 & 9.82 \\
\hline $\mathrm{Na}_{2} \mathrm{O}$ & 0.56 & 0.56 & 0.54 & 0.32 & 0.16 & 0.23 & 0.36 & 0.21 & 0.07 & 0.16 & 0.13 & 0.12 & 0.15 & 0.15 & 0.06 & 0.12 \\
\hline $\mathrm{K}_{2} \mathrm{O}$ & 4.25 & 6.48 & 5.89 & 8.34 & 5.63 & 9.04 & 4.59 & 8.10 & 2.43 & 7.24 & 6.94 & 6.95 & 6.39 & 11.17 & 0.66 & 6.25 \\
\hline $\mathrm{P}_{2} \mathrm{O}_{5}$ & 0.23 & 0.06 & 0.13 & 0.08 & 0.11 & 0.13 & 0.19 & 0.11 & 0.07 & 0.11 & 0.19 & 0.17 & 0.20 & 0.20 & 0.04 & 0.18 \\
\hline п.п.п. & 4.74 & 5.80 & 3.72 & 4.12 & 12.27 & 4.85 & 12.04 & 3.43 & 36.29 & 4.73 & 12.73 & 8.64 & 3.51 & 3.98 & 44.49 & 15.81 \\
\hline Сумма & 99.77 & 96.09 & 99.81 & 99.70 & 99.77 & 99.73 & 99.84 & 99.77 & 99.82 & 99.80 & 99.82 & 99.86 & 99.76 & 99.81 & 99.83 & 99.84 \\
\hline $\mathrm{SiO}_{2} / \mathrm{Al}_{2} \mathrm{O}_{3}$ & 5.77 & 6.43 & 5.69 & 4.97 & 5.17 & 5.21 & 4.46 & 5.47 & 4.12 & 6.45 & 5.13 & 5.54 & 5.97 & 5.57 & 2.63 & 5.80 \\
\hline $\mathrm{K}_{2} \mathrm{O} / \mathrm{Na}_{2} \mathrm{O}$ & 7.59 & 11.57 & 10.91 & 26.06 & 35.19 & 39.30 & 12.75 & 38.57 & 34.71 & 45.25 & 53.38 & 57.92 & 42.60 & 74.47 & 11.00 & 52.08 \\
\hline $\mathrm{K}_{2} \mathrm{O}+\mathrm{Na}_{2} \mathrm{O}$ & 4.81 & 7.04 & 6.43 & 8.66 & 5.79 & 9.27 & 4.95 & 8.31 & 2.50 & 7.40 & 7.07 & 7.07 & 6.54 & 11.32 & 0.72 & 6.37 \\
\hline ГМ & 0.24 & 0.18 & 0.25 & 0.23 & - & 0.23 & - & 0.19 & - & 0.22 & - & - & 0.23 & 0.20 & - & - \\
\hline $\mathrm{TM}$ & 0.05 & 0.01 & 0.03 & 0.01 & - & 0.03 & - & 0.03 & - & 0.03 & - & - & 0.05 & 0.02 & - & - \\
\hline НКМ & 0.41 & 0.69 & 0.54 & 0.66 & - & 0.75 & - & 0.74 & - & 0.67 & - & - & 0.58 & 0.94 & - & - \\
\hline ЖМ & 0.34 & 0.12 & 0.36 & 0.11 & - & 0.18 & - & 0.16 & - & 0.26 & - & - & 0.29 & 0.07 & - & - \\
\hline$\Phi \mathrm{M}$ & 0.14 & 0.06 & 0.13 & 0.09 & - & 0.09 & - & 0.07 & - & 0.11 & - & - & 0.13 & 0.05 & - & - \\
\hline Плагиоклаз, \% & - & - & - & - & 2 & - & 3 & - & 1 & - & 1 & 1 & - & - & 1 & 1 \\
\hline Ортоклаз & - & - & - & - & 24 & - & 13 & - & 12 & - & 36 & 33 & - & - & 3 & 33 \\
\hline Кварц & - & - & - & - & 25 & - & 26 & - & 5 & - & 22 & 28 & - & - & 0 & 20 \\
\hline Иллит & - & - & - & - & 16 & - & 26 & - & 4 & - & 10 & 12 & - & - & 2 & 8 \\
\hline Анкерит & - & - & - & - & 0 & - & 0 & - & 5 & - & 0 & 4 & - & - & 4 & 0 \\
\hline Серпентин & - & - & - & - & 5 & - & 6 & - & 0 & - & 3 & 0 & - & - & 0 & 2 \\
\hline Кальцит & - & - & - & - & 0 & - & 0 & - & 4 & - & 0 & 4 & - & - & 11 & 0 \\
\hline Доломит & - & - & - & - & 24 & - & 20 & - & 69 & - & 24 & 16 & - & - & 79 & 32 \\
\hline
\end{tabular}


Таблица 1. (продолжение)

Table 1. (continued)

\begin{tabular}{|c|c|c|c|c|c|c|c|c|c|c|c|c|c|c|c|}
\hline \multirow{3}{*}{ Компонент } & \multicolumn{2}{|c|}{ пачка 24} & пачка 25 & \multicolumn{2}{|c|}{ пачка 26} & пачка 27 & \multicolumn{4}{|c|}{ пачка 28} & \multicolumn{3}{|c|}{ пачка 29} & пачка 31 & пачка 32 \\
\hline & \multicolumn{15}{|c|}{ № пробы лабораторный } \\
\hline & $143697^{2}$ & $143727^{3}$ & $143696^{2}$ & $143695^{3}$ & $143726^{3}$ & $143694^{2}$ & $143693^{2}$ & $143692^{2}$ & $143725^{1}$ & $143724^{1}$ & $143691^{2}$ & $143690^{2}$ & $143723^{1}$ & $143722^{1}$ & $143721^{3}$ \\
\hline $\mathrm{SiO}_{2}$, мac. $\%$ & 49.18 & 33.00 & 48.53 & 17.70 & 14.00 & 58.88 & 57.67 & 56.46 & 67.89 & 67.07 & 49.61 & 57.19 & 64.27 & 67.92 & 6.50 \\
\hline $\mathrm{TiO}_{2}$ & 0.57 & 0.51 & 0.38 & 0.18 & 0.17 & 0.49 & 0.49 & 0.73 & 0.43 & 0.46 & 0.85 & 0.30 & 0.55 & 0.21 & 0.09 \\
\hline $\mathrm{Al}_{2} \mathrm{O}_{3}$ & 10.64 & 8.22 & 9.58 & 3.55 & 4.37 & 11.46 & 11.04 & 11.61 & 13.55 & 12.15 & 9.83 & 9.16 & 13.08 & 13.74 & 1.77 \\
\hline $\mathrm{Fe}_{2} \mathrm{O}_{\text {зобщ }}$ & 4.36 & 4.40 & 3.07 & 4.65 & 2.26 & 3.09 & 3.11 & 4.11 & 0.98 & 1.46 & 3.57 & 2.74 & 2.45 & 1.15 & 2.10 \\
\hline $\mathrm{MnO}$ & 0.13 & 0.06 & 0.10 & 0.29 & 0.08 & 0.05 & 0.06 & 0.05 & 0.01 & 0.01 & 0.06 & 0.07 & 0.01 & 0.01 & 0.10 \\
\hline MgO & 9.22 & 11.37 & 7.21 & 13.23 & 15.08 & 3.94 & 5.49 & 6.86 & 1.47 & 1.55 & 7.96 & 5.10 & 1.88 & 1.32 & 15.62 \\
\hline $\mathrm{CaO}$ & 7.53 & 13.67 & 9.55 & 23.28 & 24.16 & 5.95 & 5.65 & 3.93 & 0.57 & 2.54 & 8.38 & 6.86 & 2.75 & 0.91 & 31.00 \\
\hline $\mathrm{Na}_{2} \mathrm{O}$ & 0.12 & 0.08 & 0.18 & 0.10 & 0.07 & 0.13 & 0.14 & 0.11 & 0.13 & 0.13 & 0.10 & 0.12 & 0.11 & 0.16 & 0.06 \\
\hline $\mathrm{K}_{2} \mathrm{O}$ & 5.57 & 5.73 & 6.29 & 1.79 & 2.08 & 8.14 & 7.49 & 7.09 & 12.51 & 11.03 & 5.77 & 6.87 & 11.80 & 12.46 & 1.06 \\
\hline $\mathrm{P}_{2} \mathrm{O}_{5}$ & 0.17 & 0.14 & 0.15 & 0.13 & 0.08 & 0.18 & 0.21 & 0.20 & 0.19 & 0.19 & 0.25 & 0.13 & 0.22 & 0.08 & 0.06 \\
\hline п.п.п. & 12.20 & 22.67 & 14.64 & 34.93 & 37.47 & 7.49 & 8.40 & 8.65 & 2.00 & 3.12 & 13.43 & 10.84 & 2.73 & 1.88 & 41.47 \\
\hline Сумма & 99.71 & 99.85 & 99.68 & 99.83 & 99.82 & 99.84 & 99.82 & 99.80 & 99.83 & 99.82 & 99.81 & 99.79 & 99.85 & 99.86 & 99.83 \\
\hline $\mathrm{SiO}_{2} / \mathrm{Al}_{2} \mathrm{O}_{3}$ & 1.41 & 4.01 & 6.07 & 14.59 & 3.20 & 5.84 & 0.29 & 2.84 & 5.01 & 5.52 & 1.42 & 7.41 & 4.91 & 4.94 & 3.67 \\
\hline $\mathrm{K}_{2} \mathrm{O} / \mathrm{Na}_{2} \mathrm{O}$ & 46.42 & 71.63 & 34.94 & 17.90 & 29.71 & 62.62 & 53.50 & 64.45 & 96.23 & 84.85 & 57.70 & 57.25 & 107.27 & 77.88 & 17.67 \\
\hline $\mathrm{K}_{2} \mathrm{O}+\mathrm{Na}_{2} \mathrm{O}$ & 5.69 & 5.81 & 6.47 & 1.89 & 2.15 & 8.27 & 7.63 & 7.20 & 12.64 & 11.16 & 5.87 & 6.99 & 11.91 & 12.62 & - \\
\hline ГМ & - & - & - & - & - & - & - & - & 0.22 & 0.21 & - & - & 0.25 & 0.22 & - \\
\hline TM & - & - & - & - & - & - & - & - & 0.03 & 0.04 & - & - & 0.04 & 0.02 & - \\
\hline НКМ & - & - & - & - & - & - & - & - & 0.93 & 0.92 & - & - & 0.91 & 0.92 & - \\
\hline ЖМ & - & - & - & - & - & - & - & - & 0.07 & 0.12 & - & - & 0.18 & 0.08 & - \\
\hline$\Phi \mathrm{M}$ & - & - & - & - & - & - & - & - & 0.04 & 0.05 & - & - & 0.07 & 0.04 & - \\
\hline Плагиоклаз, \% & 1 & 1 & 2 & 1 & 1 & 1 & 1 & 1 & - & - & 1 & 1 & - & - & 1 \\
\hline Ортоклаз & 22 & 30 & 30 & 7 & 8 & 38 & 41 & 26 & - & - & 34 & 37 & - & - & 5 \\
\hline Кварц & 21 & 8 & 21 & 10 & 5 & 25 & 25 & 23 & - & - & 23 & 29 & - & - & 2 \\
\hline Иллит & 19 & 8 & 10 & 6 & 9 & 12 & 10 & 15 & - & - & 17 & 6 & - & - & 2 \\
\hline Анкерит & 0 & 0 & 0 & 12 & 5 & 0 & 2 & 0 & - & - & 0 & 0 & - & - & 5 \\
\hline Серпентин & 7 & 3 & 1 & 0 & 0 & 3 & 0 & 4 & - & - & 8 & 0 & - & - & 0 \\
\hline Кальцит & 0 & 0 & 0 & 3 & 4 & 0 & 0 & 0 & - & - & 0 & 0 & - & - & 14 \\
\hline Доломит & 24 & 45 & 30 & 60 & 69 & 17 & 17 & 26 & - & - & 12 & 22 & - & - & 71 \\
\hline
\end{tabular}

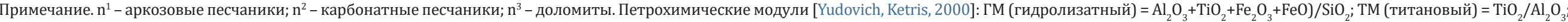

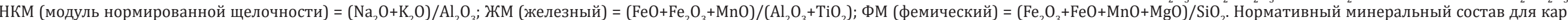
бонатных пород рассчитан с использованием программы MINLITH [Rosen et al., 2000]. Прочерк - расчеты не производились.

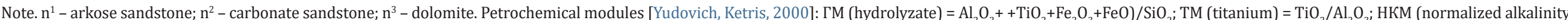

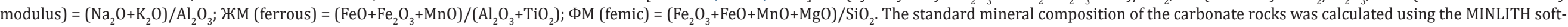
ware [Rosen et al., 2000]. Dash - no calculations. 